J. L. Stoyenoff · J. A. Witter · M. E. Montgomery

C. A. Chilcote

\title{
Effects of host switching on gypsy moth (Lymantria dispar (LL)) under field conditions
}

Received: 8 February 1993/Accepted: 9 November 1993

\begin{abstract}
Effects of various single and two species diets on the performance of gypsy moth (Lymantria dispar (L.)) were studied when this insect was reared from hatch to pupation on intact host trees in the field. The tree species used for this study were red oak (Quercus rubra L.), white oak (Q. alba L.), bigtooth aspen (Populus grandidentata Michaux), and trembling aspen (P. tremuloides Michaux). These are commonly available host trees in the Lake States region. The study spanned two years and was performed at two different field sites in central Michigan. Conclusions drawn from this study include: (1) Large differences in gypsy moth growth and survival can occur even among diet sequences composed of favorable host species. (2) Larvae that spent their first two weeks feeding on red oak performed better during this time period than larvae on all other host species in terms of mean weight, mean relative growth rate (RGR), and mean level of larval development, while larvae on a first host of bigtooth aspen were ranked lowest in terms of mean weight, RGR, and level of larval development. (3) Combination diets do not seem to be inherently better or worse than diets composed of only a single species; rather, insect performance was affected by the types of host species eaten and the time during larval development that these host species were consumed instead of whether larvae ate single species diets or mixed species diets. (4) In diets composed of two host species, measures of gypsy moth performance are affected to different extents in the latter part of the season by the two different hosts; larval weights and development
\end{abstract}

\section{J. L. Stoyenoff $(\bigotimes) \cdot$ J. A. Witter}

School of Natural Resources and Environment, University of Michigan,

Ann Arbor, MI 48109-1115, USA

M. E. Montgomery

Northeastern Forest Experiment Station, USDA Forest Service, Hamden, CT 06514, USA

C. A. Chilcote

Entomology Department, Michigan State University, East Lansing, MI 48824, USA rates show continued effects of the first host fed upon while RGRs, mortality, and pupal weights are affected strongly by the second host type eaten. (5) Of the diets investigated in this study, early feeding on red oak followed by later feeding on an aspen, particularly trembling aspen, is most beneficial to insects in terms of attaining high levels of performance throughout their lives.

Key words Host switching - Insect/plant interactions Gypsy moth · Diet sequences

\section{Introduction}

The gypsy moth is a highly polyphagous folivore which will feed on over 300 species of woody plants (Leonard 1981). Among its favored foods are oaks and aspens. Newly hatched gypsy moth larvae are carried to hosts by wind dispersal in the spring, landing on plants and then either remaining to feed or redispersing (Capinera and Barbosa 1976; Lance and Barbosa 1981). Once a host plant has been accepted, larvae typically remain on foliage for the first three instars (Lance and Barbosa 1979; Leonard 1981). At the end of this time, however, larvae show a change in feeding behavior (Leonard 1970). They become nocturnal feeders at low to moderate population densities, feed both day and night at high population densities, begin to wander, and may now switch host plants (Barbosa 1978a; Leonard 1981; Rossiter 1981; Lance and Barbosa 1982; Mauffette and Lechowicz 1984; Liebhold et al. 1986). Research has shown that substantial tree switching takes place both in low and high density gypsy moth populations (Lance and Barbosa 1982; Liebhold et al. 1986). Between-tree movement is accentuated by higher insect numbers so that each day there may be $30 \%$ of the larvae switching host trees in high density populations (Liebhold et al. 1986). Under outbreak conditions, insects may experience increased restlessness and wandering, and defoliation of host trees may force larvae to switch hosts (Leon- 
ard 1967; Rafes and Gninenko 1973; Doane and Leonard 1975; Lance and Barbosa 1979). While some movement will take place between conspecific trees, much of the movement in mixed stands may occur between trees of different species. Therefore, many gypsy moths may experience multiple hosts in their diets.

Species of host plant consumed has been shown to greatly affect performance of a variety of lepidopteran larvae (Drooz 1965, 1970; Soo Hoo and Fraenkel 1966; Beckwith 1976; Scriber 1979, 1981; Koller and Leonard 1981; Feeny et al. 1985; Beach and Todd 1988; Garcia 1988). A number of studies have examined effects of various individual host species on growth and survival of the gypsy moth as well (Hough and Pimentel 1978; Barbosa and Greenblatt 1979; Barbosa et al. 1983; Meyer and Montgomery 1987; Rossiter et al. 1988; Hajek 1989; Miller and Hanson 1989; Chilcote 1990; Lindroth and Hemming 1990; Sheppard and Friedman 1990; Miller et al. 1991; Roden and Surgeoner 1991; Chilcote et al. 1992). However, effects of a given host species on insect performance may be quite different when an insect feeds exclusively upon that host species rather than when that host species is consumed as only one element in a sequential diet. Persistent physiological effects, such as induction of digestive enzymes or detoxification enzymes, due to food that was consumed either earlier in an instar or by younger instars have been seen in many lepidopteran larvae (Ishaaya and Swirski 1976; Schoonhoven and Meerman 1978; Brattsten 1979; Scriber 1979, 1981, 1982; Grabstein and Scriber 1982; Yu 1982; Ahmad 1983; Karowe 1989). Behavioral induction, in which prior feeding experience causes a modification in insects' preference for or acceptance of later host plants, is also rather widespread among lepidopteran larvae and in some cases can be very long-lasting (Jermy et al. 1968; Yamamoto 1974; Hanson 1976, 1983; Scriber 1979; Grabstein and Scriber 1982). These studies have shown that prior feeding experience can cause insects to perform differently on a particular host species depending upon the types of host species that have been consumed previously by the insect.

A study of gypsy moth larvae fed on a variety of single and two-species diets provides the opportunity to examine effects of host switching and compare the differential impacts of initial and subsequent host plants on an herbivore that can be either polyphagous or monophagous at the level of the individual. Diets composed of single host plants, two or more congeneric host plants, and two or more non-congeneric host plants are all realistic situations that frequently occur for gypsy moth in nature. However, very little work has been done examining the effects of host switching or the impacts of multiple hosts on gypsy moth performance (Barbosa et al. 1986; Roden and Surgeoner 1991). The studies which have been conducted to date have not examined the impacts of multiple species diets on gypsy moth under field conditions or on intact host plants.

Our study provides information about effects of various single and two species diets on gypsy moth larvae that have been caged on intact host plants in the field in Michigan from time of hatch until time of pupation. It addresses several questions: (1) What are the effects of various host species on early larval performance, as measured by survival, weight, growth, and development levels, before any host switching takes place? (2) What are the effects of various two species diets on measures of later larval performance and on pupal characteristics? (3) How do combination diets compare with single species diets in terms of benefiting gypsy moth performance? (4) What is the relative impact of the two different species in a combination diet on the various measures of gypsy moth performance? and (5) Are certain diet sequences particularly advantageous for the gypsy moth and if so, which ones and why?

\section{Materials and methods}

Host plant species and study sites

In 1989, the tree species used as hosts for this study were red oak (Quercus rubra L.), white oak (Q. alba L.), bigtooth aspen (Populus grandidentata Michx.), and trembling aspen ( $P$. tremuloides Michx.). At the 1990 study site, bigtooth aspen was omitted because it was not available under the same microsite conditions as the other three species. Species selected are commonly found throughout the Lake States region and are important, preferred host plants of the gypsy moth. These species are frequently found in mixed stands in Michigan and represent a very realistic menu of plants that an individual gypsy moth caterpillar may move between within stands. Also, use of these species allows us to examine diet sequences composed of both congeneric and noncongeneric pairs.

Plots were located on dry-mesic sites that were dominated by ten to fifteen year old trees of the study species. Understory-sized trees were used so that their crowns could be easily reached with $3 \mathrm{~m}$ ladders; additionally, Ticehurst and Yendol (1989) have demonstrated that the understory is a very important location for gypsy moth/plant interactions. The study areas for 1989 and 1990 , respectively, were located in Crawford County (T26N, R3W, S28) and Kalkaska County (T25N, R6W, S26), Michigan, USA.

\section{Insects}

Gypsy moth egg masses were collected from the leading edge of an expanding infestation in central Michigan. Egg masses were surface sterilized and stored at $5^{\circ} \mathrm{C}$ (ODell et al. 1985). Hatch took place in a $25^{\circ} \mathrm{C}$ incubator and was timed to coincide with natural gypsy moth eclosion in the field. Insects used in the study were collected from egg masses during the second and third days that larvae hatched from a given egg mass.

Field procedures

Neonate larvae were placed on trees in fine mesh sleeve bags of the type which have been shown to have no effect on phenolic chemistry of enclosed oak leaves (Rossiter et al. 1988). Ten larvae, each originating from a different egg mass to help ensure a genetically diverse group, were placed into each sleeve bag. Six sleeve bags were put on every study tree. In 1989, 16 trees each of red oak, white oak, bigtooth aspen, and trembling aspen were used, supporting a total of 384 bags that caged 3840 larvae. In 1990, ten trees each of red oak, white oak, and trembling aspen were used, supporting 180 bags caging 1800 larvae. At the time insects were placed on the trees, the level of bud and leaf development of each 
Table 1 All possible diet combinations with four host species. ${ }^{2}$ Each of the 16 combinations was used in 1989 , but only the nine combinations that do not involve BT were used in 1990 since BT was not a study species in that year

\begin{tabular}{lllll}
\hline \multirow{2}{*}{ First host } & \multicolumn{3}{l}{ Second host } & \\
\cline { 2 - 5 } & RO & WO & TA & BT \\
\hline RO & RO-RO & RO-WO & RO-TA & RO-BT \\
WO & WO-RO & WO-WO & WO-TA & WO-BT \\
TA & TA-RO & TA-WO & TA-TA & TA-BT \\
BT & BT-RO & BT-WO & BT-TA & BT-BT \\
\hline
\end{tabular}

a $\mathrm{RO}=$ red oak; $\mathrm{WO}=$ white oak; $\mathrm{TA}=$ trembling aspen; $\mathrm{BT}=$ bigtooth aspen

study tree was scored using the phenological scoring system outlined in Chilcote (1990).

After placement in the field, larvae fed undisturbed for two weeks. At the end of this time, bags were removed from the trees, dead larvae counted, and surviving larvae individually weighed to the nearest $\mathrm{mg}$ on an electronic balance. Larvae were generally off the foliage for approximately $24 \mathrm{hr}$ at the time of weighing. They were stored at $5^{\circ} \mathrm{C}$ during this entire time except for the brief period during which larvae from a particular bag were being weighed. An instar determination was made for each living individual. The host switch was performed at the end of this weighing.

To perform the host switch in 1989 , the 64 study trees were divided into eight groups of eight trees each, every group containing two white oaks, two red oaks, two bigtooth aspens, and two trembling aspens. Generally groups were formed from trees located as close together as possible to minimize microsite differences. Host switches took place between the trees within each group so that all of the possible diet combinations were represented in every group of trees (Table 1). Three bags from each of the species in the group were sent to trees in the group of each of the other species. The three bags were selected so that both trees in the group of the sending species were represented in a given switch type. Likewise, the three bags were distributed so that both trees of the receiving species had representation in a given switch type. Finally, three bags from one tree of each species in the group were used as controls and were simply switched to new branches on the same tree. Overall 24 bags, or a potential 240 individuals, were sent in each of the possible switch directions in 1989.

The switch was performed similarly in 1990 . However, in 1990 there were ten groups of three trees each (one white oak, one red oak, and one trembling aspen), and two bags went in each switch direction in every group. Therefore, 20 bags represented each switch direction.

In both years, larvae fed on their second host plant for two weeks after the host switch, and then they were weighed again. However, larvae were not switched to new host plants after this second weighing; rather, they were returned to the same tree that they had been on since the host switch took place. Larvae were weighed for a third and final time four weeks after the switch, or six weeks after initial placement as neonates in the field. After this, a randomized cull was performed to reduce the number of larvae in each bag to five, since older larvae consume foliage so rapidly. This measure to prevent food shortage was accompanied with the precaution of monitoring sleeve bags throughout larval development and supplying more food whenever larvae had consumed $50 \%$ of the foliage contained in a bag. This was done by inserting more leaf material from the same branch into the mouth of the sleeve bag.

After the third weighing, bags were returned to the same host tree and remained there through the pupation period. They were monitored every two to three days so that pupae could be collected, weighed, and sexed as they formed. Pupal weights have been shown to be highly correlated with adult fecundity levels in the gypsy moth as well as in other lepidopteran species and thus are important measures of potential adult reproductive performance (Drooz 1965; Beckwith 1976; Hough and Pimentel 1978).

Results are reported by gender for pupal weights and total developmental time (hatch to pupation) due to strong differences which occur in these parameters between the sexes. While some differences between the sexes also occur earlier during larval development, it was not possible within the time and material constraints of our experiment to sex the required numbers of larvae necessary in order to report all larval variables by gender. Because of the large sample sizes (1989:960 insects on each first or second host species, or 240 insects per each first host/second host combination; 1990:600 insects on each first or second host species, or 200 insects per each first host/second host combination) and randomization used in our experiment, it is unlikely that there were any imbalances in sex ratios between treatment types that were serious enough to meaningfully affect the results.

\section{Numerical procedures}

Weights of larvae were used to calculate relative growth rate (RGR). RGRs were determined during each two week period as:

$$
\mathrm{RGR}=[(\operatorname{InWt2}-\mathrm{InWt} 1) /(\mathrm{DD} 2-\mathrm{DD} 1)] \times 1000
$$

where $W t 1$ and $W t 2$ represent the weight in $m g \times 10$ at the beginning and end of the period respectively, and DD1 and DD2 represent the degree days accumulated before the beginning of the period and up to the end of the period respectively (Kogan and Cope 1974). Degree days were calculated by the Allen sine wave method (Allen 1976) using a base temperature of $6.8^{\circ} \mathrm{C}$ which was obtained by averaging temperatures provided in a gypsy moth phenological model developed by Sheehan (1992). The resulting RGR has units of $\mu \mathrm{g}$ of weight gained/mg of body weight/degree day ${ }^{\circ} \mathrm{C}$.

Larval mortality was calculated as number of larvae in a cage dying during a two week period divided by number of larvae alive in the cage at the beginning of the two week period.

Statistical analyses were performed with the General Linear Models (GLM) procedure in SAS (SAS 1985). The statistical design for the first stage of the experiment, before the host switch was made, was a two factor nested design. Tree (factor 1) was nested under host type (factor 2). The sampling unit was the sleeve bag. Level of leaf development at the time of insect placement in the field was used as a covariate.

The statistical design for the second stage of the experiment, after the host switch was made, was a randomized block design with split plots (Neter et al. 1990) (Table 2). The blocking factor was switch group (factor A); there were eight blocks in 1989 and ten blocks in 1990 . The plots were groups of insects that were treated with the various types of second host diet (factor B). There were four plots per block for a total of 32 plots in 1989, and three plots per block for a total of 30 plots in 1990 . These plots were divided into subplots on the basis of initial diet fed to the insects (factor C). There were four subplots per plot for a total of 128 subplots in 1989, and three subplots per plot for a total of 90 subplots in 1990. The sampling unit in both years was the sleeve bag. There were three sleeve bags per subplot in 1989 and two sleeve bags per subplot in 1990 . The weight at the previous weighing period was used as a covariate for tests involving weight or RGR, while the instar at the previous weighing period was used as a covariate in tests of insect development.

In performing the analysis of the 1989 data, the two trees which were of the same species within each switch group were considered as a unit. The validity of this assumption was tested by examining the differences in insect performance on the paired trees in the two week period just before the switching experiment took place. This was done by using a one way ANOVA. We also examined differences that existed in leaf development between the paired trees. Important differences were found between paired trees in two of the original ten switch groups. The two groups with differences were discarded, leaving the eight switch groups which are referred to in these methods. In 1990, such a situation did not 
Table 2 ANOVA table for the split-plot design model used in study after the host switch. SS is sum of squares, d.f. is degrees of freedom, $\mathrm{MS}$ is mean square, and $\mathrm{E}(\mathrm{MS})$ is expected mean square

\begin{tabular}{|c|c|c|c|c|c|}
\hline Source & SS & d.f. & MS & E(MS) & $F v_{1}, v_{2}$ \\
\hline $\begin{array}{l}\text { Whole plot } \\
\text { A } \\
\text { B } \\
\text { AB }\end{array}$ & $\begin{array}{l}\mathrm{SS}_{\mathrm{A}} \\
\mathrm{SS}_{\mathrm{B}} \\
\mathrm{SS}_{\mathrm{AB}}\end{array}$ & $\begin{array}{l}\mathrm{I}-1 \\
\mathrm{~J}-1 \\
(\mathrm{I}-1)(\mathrm{J}-1)\end{array}$ & $\begin{array}{l}\mathrm{MS}_{\mathrm{A}} \\
\mathrm{MS}_{\mathrm{B}} \\
\mathrm{MS}_{\mathrm{AB}}\end{array}$ & $\begin{array}{l}\sigma^{2}+\mathrm{JK} \sigma_{\mathrm{A}}^{2} \\
\sigma^{2}+\mathrm{K} \sigma_{\mathrm{AB}}^{2}+\mathrm{IK} \sigma_{\mathrm{B}}^{2} \\
\sigma^{2}+\mathrm{K} \sigma_{\mathrm{AB}}^{2}\end{array}$ & $\mathrm{~F}_{\mathrm{J}-1,(\mathrm{I}-1)(\mathrm{J}-1)}$ \\
\hline $\begin{array}{l}\text { Split plot } \\
\text { C } \\
\text { AC } \\
\text { BC } \\
\text { ABC }\end{array}$ & $\begin{array}{l}\mathrm{SS}_{\mathrm{C}} \\
\mathrm{SS}_{\mathrm{AC}} \\
\mathrm{SS}_{\mathrm{BC}} \\
\mathrm{SS}_{\mathrm{ABC}}\end{array}$ & $\begin{array}{l}\mathrm{K}-1 \\
(\mathrm{I}-1)(\mathrm{K}-1) \\
(\mathrm{J}-1)(\mathrm{K}-1) \\
(\mathrm{I}-1)(\mathrm{J}-1)(\mathrm{K}-1)\end{array}$ & $\begin{array}{l}\mathrm{MS}_{\mathrm{C}} \\
\mathrm{MS}_{\mathrm{AC}} \\
\mathrm{MS}_{\mathrm{BC}} \\
\mathrm{MS}_{\mathrm{ABC}}\end{array}$ & $\begin{array}{l}\sigma^{2}+\mathrm{J} \sigma_{\mathrm{AC}}^{2}+\mathrm{IJ} \sigma_{\mathrm{C}}^{2} \\
\sigma^{2}+\mathrm{J} \sigma_{\mathrm{AC}}^{2} \\
\sigma^{2}+\sigma_{\mathrm{ABC}}^{2}+\mathrm{I} \sigma_{\mathrm{BC}}^{2} \\
\sigma^{2}+\sigma_{\mathrm{ABC}}^{2}\end{array}$ & $\begin{array}{l}F_{\mathrm{a}-1,(\mathrm{I}-1)(\mathrm{K}-1)} \\
\mathrm{F}_{(\mathrm{J}-1)(\mathrm{K}-1),(\mathrm{I}-1)(\mathrm{J}-1)(\mathrm{K}-1)} \\
\end{array}$ \\
\hline Total & $\mathrm{SS}_{\mathrm{T}}$ & IJK-1 & - & - & - \\
\hline
\end{tabular}

${ }^{a}$ No exact F-test for $\mathrm{A}$ and $\mathrm{AC}$

occur because in that year there was only one tree of each species within each switch group so no pairing took place.

Assumptions of all models were tested using plots of the residuals versus the predicted values, normal probability plots, stemand-leaf plots, and skewness and kurtosis coeeficients. Where necessary, square root transformations were performed on the data before analysis to more closely meet assumptions of normality and homogeneity.

Scheffe's multiple comparison procedure was used in the evaluation of the data. This procedure was employed for tests of all pairwise comparisons because its relatively low power reduces the risk of Type I error. An experimentwise $\alpha$ of 0.05 was used.

\section{Results}

Effects of host species on young larvae

Neonate larvae caged on red oak attained greater average weights after two weeks of feeding than did larvae on any other host species. In 1989, these insects were significantly heavier on average than insects feeding on either white oak or bigtooth aspen (ANOVA $p=0.024$ for species) (Fig. 1a). Red oak-fed larvae once again ranked as the heaviest insects on average after the initial feeding period in 1990, although the difference was not statistically significant in this year (ANOVA $p=0.115$ for species) (Fig. 1b). The covariate of leaf phenology was not significant in either year (ANOVA 1989 $p=0.077,1990 p=0.332$ ).

Likewise, red oak-fed larvae had the highest ranked RGRs during the first two weeks of feeding in both years of the study (Fig. 1c and d), being significantly higher than mean RGRs of white oak-fed larvae in either year and significantly greater than the mean RGR of bigtooth aspen-fed larvae in 1989 when this species was included as a host (ANOVA $1989 p=0.005,1990$ $p=0.005$ for species). In both years, mean RGRs of red oak-fed larvae were not significantly different from those of trembling aspen-fed larvae. The covariate of leaf phenology was not significant in either year (ANOVA $1989 p=0.174,1990 p=0.171$ ).

Red oak-fed insects ranked as the fastest in terms of mean larval development. In 1989, these insects were on average 0.4 stadium ahead of and significantly different from the slowest developing group of larvae, which had been feeding on bigtooth aspen during the first two weeks of development (mean \pm standard error: red oak $=2.6 \pm 0.04$ stadia; trembling aspen $=2.4 \pm 0.04$ stadia; white oak $=2.3 \pm 0.04$ stadia; bigtooth aspen $=2.2 \pm 0.03$ stadia; ANOVA $p=0.006$ for species). In 1990, red oak-fed larvae were significantly different from and 0.5 stadium ahead of the slowest developing group of larvae, which had fed on trembling aspen (red oak $=2.7 \pm 0.03$ stadia; white oak $=2.6 \pm 0.05$ stadia; trembling aspen $=2.2 \pm 0.04$ stadia; ANOVA $p=0.007$ for species). The covariate of leaf phenology was not significant in either year (ANOVA $1989 p=0.369,1990$ $p=0.454$ ).

Larval mortality for the first two week period was only evaluated in 1989 . While not statistically significant (ANOVA $p=0.453$ for species), insects feeding on white oak experienced $16 \% \pm 2$ mortality on average, followed by $8 \% \pm 1$ on bigtooth aspen, $7 \% \pm 1$ on red oak, and only $5 \% \pm 1$ on trembling aspen. The covariate of leaf phenology was not significant in either year (ANOVA $1989 p=0.901,1990 p=0.516$ ).

Overall, larvae that spent their first two weeks feeding on red oak ranked ahead of larvae on all other host species in terms of mean weight, mean RGR, and mean larval development. Larvae from bigtooth aspen, when this host species was included in the experiments, were ranked behind all others in terms of mean weights, RGRs, and development. In 1989, larvae on white oak suffered the highest mean percent mortality during the first two weeks of larval feeding.

\section{Effects of host switching on older larvae}

\section{Larval weights}

Larval weights continued to be significantly affected by the first host species fed upon in a diet sequence even after larvae had been switched to a second host species for a period of two weeks (ANOVA $1989 p=0.023,1990$ 

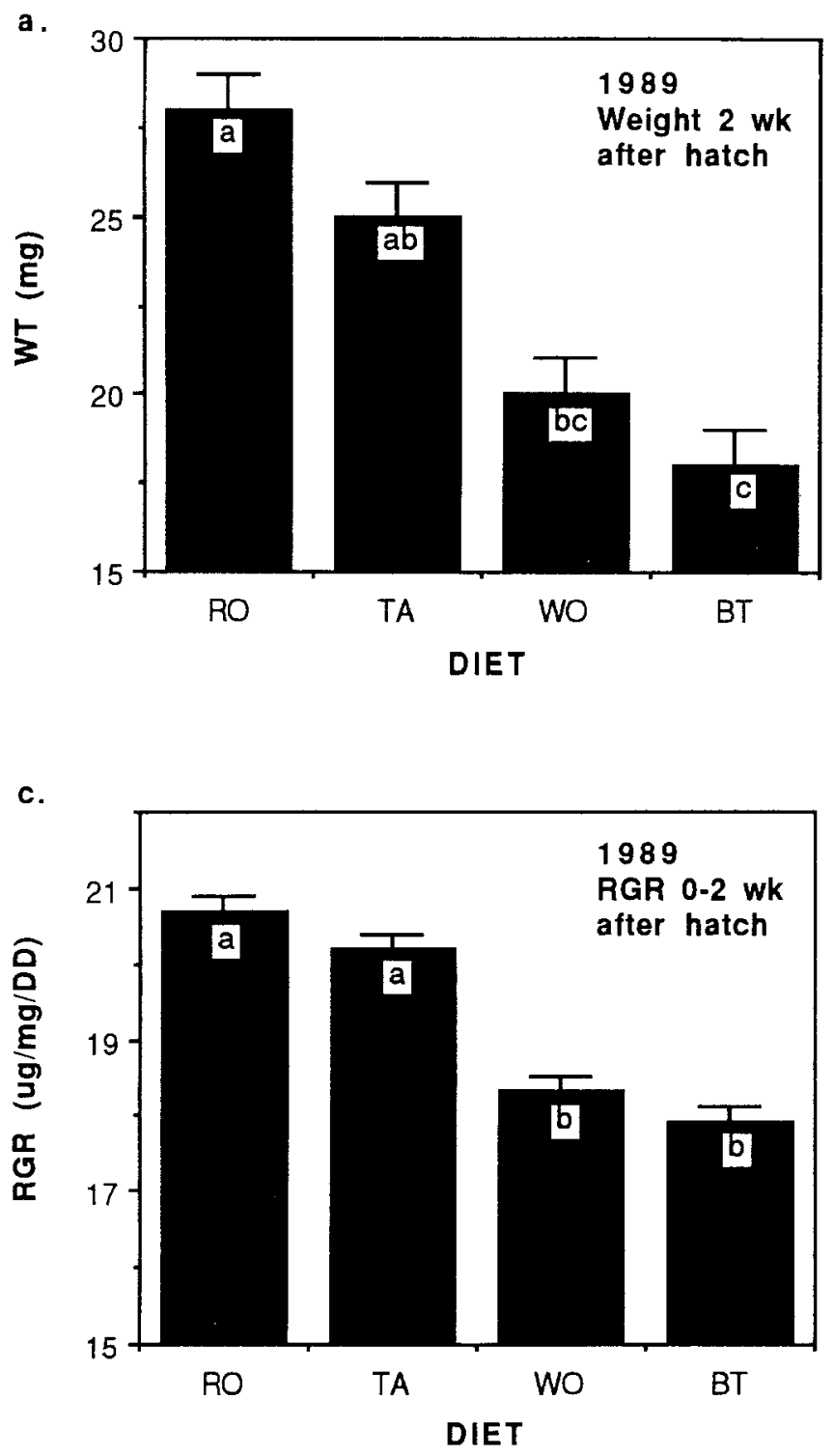

Fig. 1a-d Mean larval weights two weeks after hatch on the various diet types in 1989 (a) and 1990 (b); mean larval RGRs for the two week period after hatch on the various diet types in 1989 (c) and $1990(\mathbf{d}),(R O=$ red oak; $W O=$ white oak; $T A=$ trembling aspen; $B T=$ bigtooth aspen. Bars indicate standard errors. Different letters indicate mean values that are significantly different)

$p=0.001$ for first host). In both 1989 and 1990 , insects that spent their first two weeks feeding on red oak had significantly higher average weights than all other larvae two weeks after the host switch (Fig. 2). Insects that fed on trembling aspen or white oak before the host switch were variable in position relative to one another after the switch but significantly lower in terms of mean weights than insects started on red oak (Fig. 2). Those insects that fed on bigtooth aspen before the host switch had the lowest ranked mean weight two weeks after the switch but were not significantly different from insects eating a first host of white oak in 1989. The same rank order pattern in terms of effects of first host on later
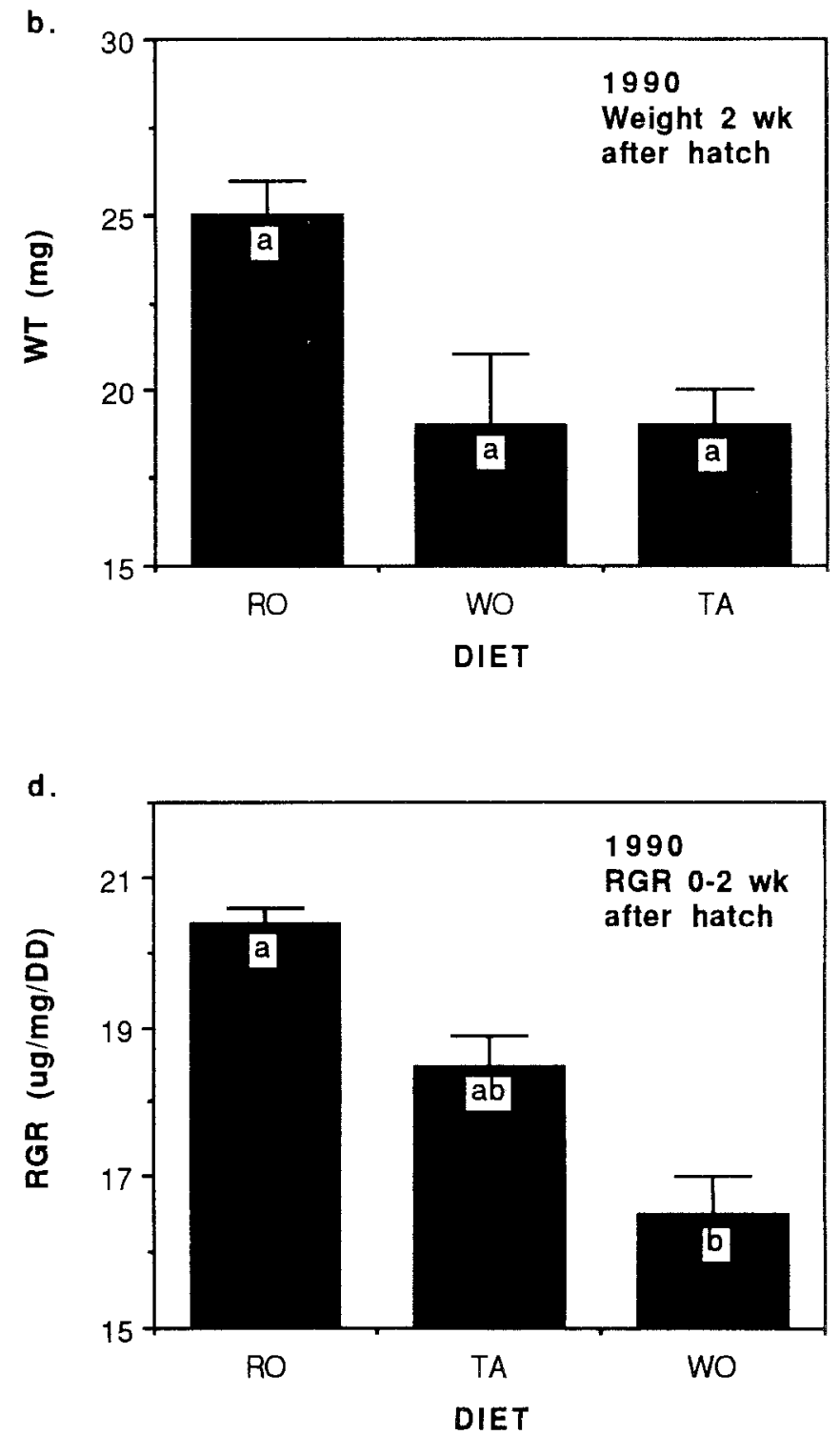

larval weights that is seen two weeks after the host switch in both years is observed four weeks after the host switch in both years as well, but the differences then were not strong enough to be statistically significant (ANOVA $1989 p=0.118, p=0.857$ for first host).

The second host fed upon in a diet sequence affected larval weights significantly two weeks after larvae switched to their new host and continued to significantly affect weights for the remainder of the larval feeding period. Two weeks after the host switch in both years, insects that shared a new host of white oak were ranked as the heaviest larvae on average while those whose new host was trembling aspen were ranked as the lightest; difference in average weights on these two species were significant in 1989 (ANOVA $p=0.011$ for second host) (Fig. 3a and b). This situation was reversed by four weeks after the host switch, however (Fig. 3c and d). In both years, by four weeks after the host switch, insects eating aspens as their second hosts were on average heavier than larvae that ate oak as the second element 

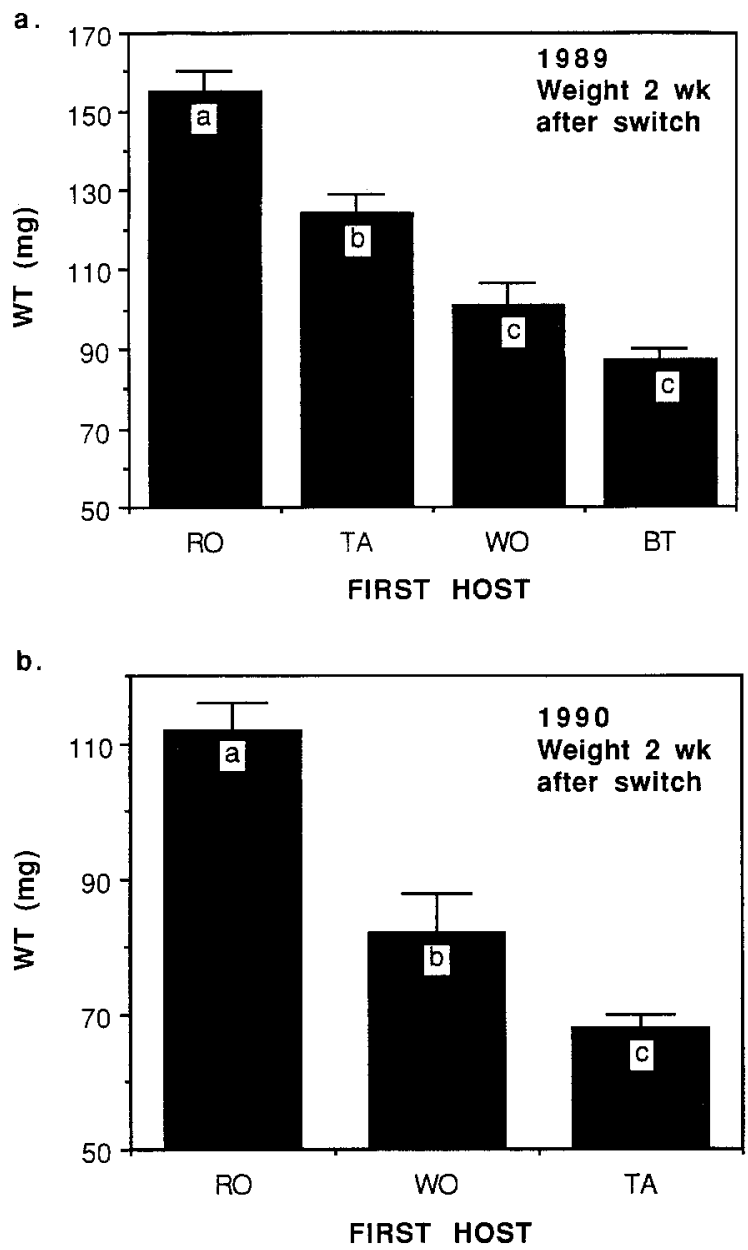

Fig. 2a, b Mean weights of larvae from different initial host species two weeks after a host switch in 1989 (a) and 1990 (b). $(R O=$ red oak; $W O=$ white oak; $T A=$ trembling aspen; $B T=$ bigtooth aspen. Bars indicate standard errors. Different letters indicate mean values that are significantly different)

of their diets (ANOVA $1989 p=0.0001,1990 p=0.001$ for second host). This oak-aspen trend and its reversal after four weeks on the new host species are strongly apparent in RGR data as well.

Interactions between the first and second host species consumed by larvae were not significant in affecting mean larval weights at either two weeks (ANOVA $p=0.518$ ) or four weeks (ANOVA $p=0.179$ ) after the host switch in 1990. However, in 1989 the interaction was significant at both two weeks (ANOVA $p=0.014$ ) and four weeks (ANOVA $p=0.003$ ) after the switch. The covariate of weight at the previous sampling period was significant in both years for both weighing periods after the host switch (ANOVA $p=0.0001$ for all times).

\section{Relative growth rates}

During the two week period immediately after the host switch in both years, mean RGRs were significantly affected by the second type of food that larvae consumed,
Table 3 Mean RGRs (mg/mg/DD) for the period starting two weeks after the host switch and ending four weeks after the switch for larvae on the various diet sequences, ranked from largest to smallest RGR ${ }^{\mathrm{a}}$

\begin{tabular}{lllll}
\hline 1989 & & & & \\
\cline { 1 - 1 } Diet & RGR & & Diet & RGR \\
\hline WO-TA & $9.4 \pm 0.3$ & & WO-TA & $10.0 \pm 0.4$ \\
BT-TA & $9.2 \pm 0.3$ & & TA-TA & $9.1 \pm 0.3$ \\
TA-TA & $8.9 \pm 0.3$ & & RO-TA & $9.1 \pm 0.4$ \\
RO-TA & $8.7 \pm 0.2$ & & TA-RO & $8.3 \pm 0.3$ \\
WO-BT & $8.2 \pm 0.3$ & & WO-RO & $8.0 \pm 0.3$ \\
BT-BT & $7.8 \pm 0.3$ & & RO-RO & $7.7 \pm 0.3$ \\
TA-BT & $7.8 \pm 0.3$ & & TA-WO & $7.4 \pm 0.4$ \\
BT-WO & $7.7 \pm 0.2$ & & WO-WO & $7.3 \pm 0.3$ \\
WO-RO & $7.5 \pm 0.4$ & & RO-WO & $6.5 \pm 0.3$ \\
BT-RO & $7.3 \pm 0.3$ & & & \\
WO-WO & $7.0 \pm 0.3$ & & & \\
TA-RO & $6.9 \pm 0.5$ & & \\
TA-WO & $6.9 \pm 0.3$ & & \\
RO-BT & $6.6 \pm 0.4$ & & \\
RO-RO & $6.5 \pm 0.3$ & & \\
RO-WO & $5.8 \pm 0.2$ & & \\
\hline
\end{tabular}

${ }^{\mathrm{a}} \mathrm{RO}=$ red oak; $\mathrm{WO}=$ white oak; $\mathrm{TA}=$ trembling aspen; $\mathrm{BT}=$ bigtooth aspen Standard errors included

with insects on second hosts of oaks having RGRs ranked higher than insects that had been moved to aspen species as their second hosts (ANOVA 1989 $p=0.006,1990 p=0.004$ for second host) (Fig. 4a and b). Once larvae had been exposed to a second host plant for four weeks, however, the oak-aspen trend was reversed and diets with trembling aspen as the second element were yielding larvae with significantly better mean RGRs than diets ending in oaks in both years (ANOVA $1989 p=0.0001,1990 p=0.0001$ for second host) (Fig. 4c and $\mathrm{d}$, Table 3). Carry-over effects of the first host species eaten on RGRs attained later in the season were not strong enough to be statistically significant in either year at either weighing period after the switch (ANOVA for first host at sample 1 after switch: $1989 p=0.245$, $1990 p=0.201$; ANOVA for first host at sample 2 after switch: $1989 p=0.643,1990 p=0.438$ ). Interactions between first and second host species consumed were not significant in either year for either weighing session (ANOVA sample 1 after switch: $1989 p=0.053,1990$ $p=0.615$; ANOVA sample 2 after switch: 1989 $p=0.512,1990 p=0.351$ ). The covariate of insect weight at previous sampling period was significant at both weighing sessions in 1989 (ANOVA $p=0.0001$ for both times) and 1990 (ANOVA sample $1 p=0.001$, sample 2 $p=0.019$ ).

\section{Larval mortality}

There were no significant effects on larval mortality due to first host species eaten at either year or at either sampling period after the switch (ANOVA for first host at sample 1 after switch: $1989 p=0.407,1990 p=0.427$; 

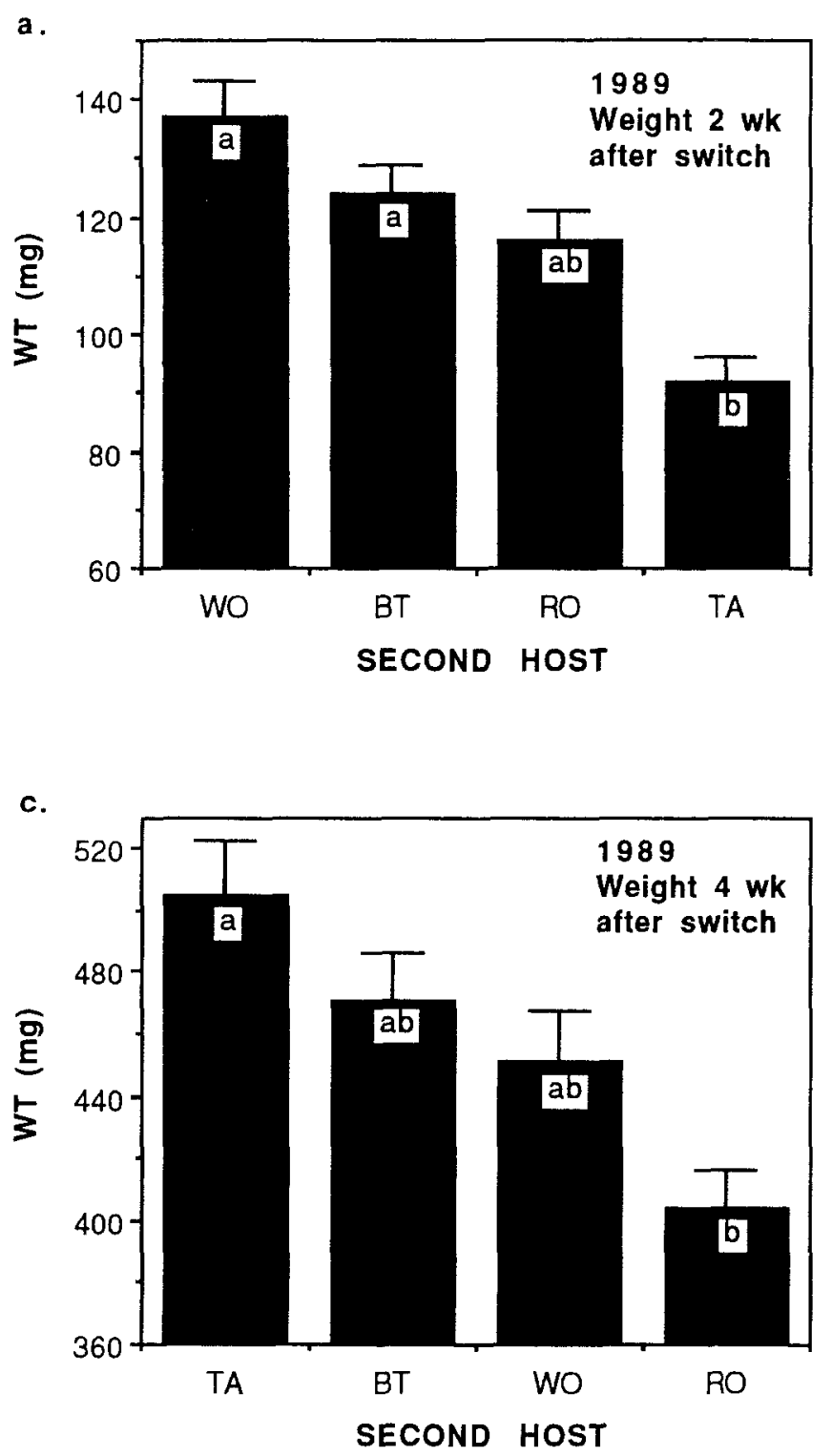

Fig. 3a-d Mean weights of larvae on different second host species two weeks after a host switch in 1989 (a) and 1990 (b), and four weeks after the switch in 1989 (c) and 1990 (d). (RO= red oak; $W O=$ white oak; $T A=$ trembling aspen; $B T=$ bigtooth aspen. Bars indicate standard errors. Different letters indicate mean values that are significantly different)

ANOVA for first host at sample 2 after switch: 1989 $p=0.941,1990 p=0.912$ ). However, larval mortality two weeks after the host switch was significantly affected by the second host species fed upon in the diet sequence (ANOVA $1989 p=0.008,1990 p=0.004$ for second host). Larvae that shared a second host species of trembling aspen suffered significantly greater average percent mortality than larvae on any other species during the two weeks after the host switch in 1990 (trembling aspen $=12 \% \pm 2 ; \quad$ red $\quad$ oak $=3 \% \pm 1 ; \quad$ white oak $=3 \% \pm 1$; ANOVA $p=0.004$ for second host). They also had the highest mean percent mortality during the
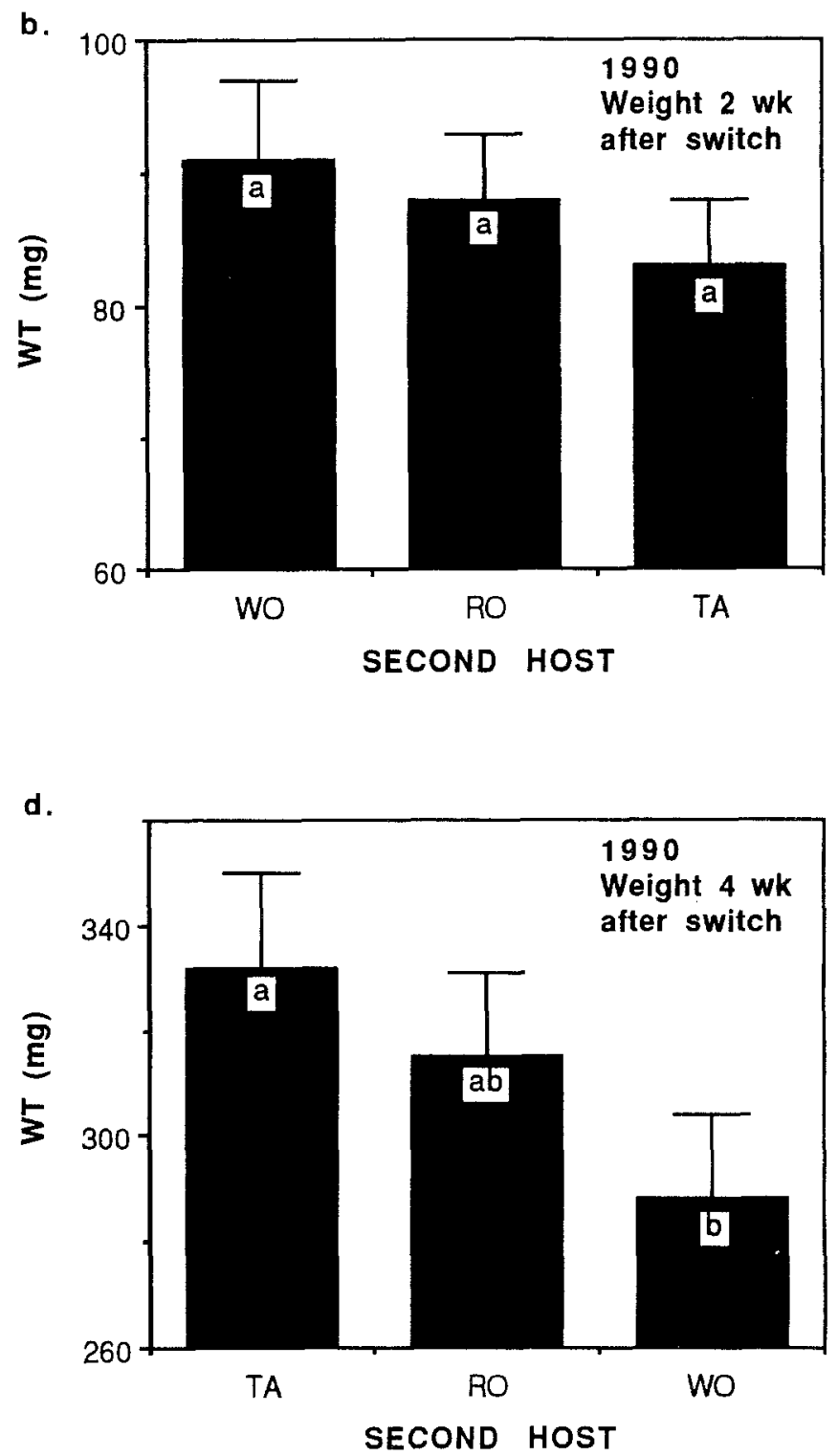

two weeks after the switch in 1989 (trembling aspen $=8 \% \pm 1 ;$ red oak $=4 \% \pm 1$; bigtooth aspen $=3 \% \pm 1$; white oak $=2 \% \pm 1$; ANOVA $p=0.008$ for second host). During the period from two weeks to four weeks after the host switch in both 1989 and 1990, larvae feeding on a second host of trembling aspen had the highest ranked mean percent mortality (1989: trembling aspen $=11 \% \pm 2$, bigtooth aspen $=9 \% \pm 1$, red oak $=8 \% \pm 1$, white oak $=7 \% \pm 1 ; 1990$ : trembling aspen $=8 \% \pm 2$, red oak $=3 \% \pm 1$, white oak $=3 \% \pm 1$ ). However, these values were not great enough to be statistically significant (ANOVA $1989 p=0.594,1990$ $p=0.063$ for second host). A ranked list of mean percent mortality on the various switch types for the two week period immediately after the host switch in both years clearly demonstrates the clustering of trembling aspenended diets at the top of this scale (Table 4). No significant interactions between the first host and the second host were present in either year at either sampling peri- 

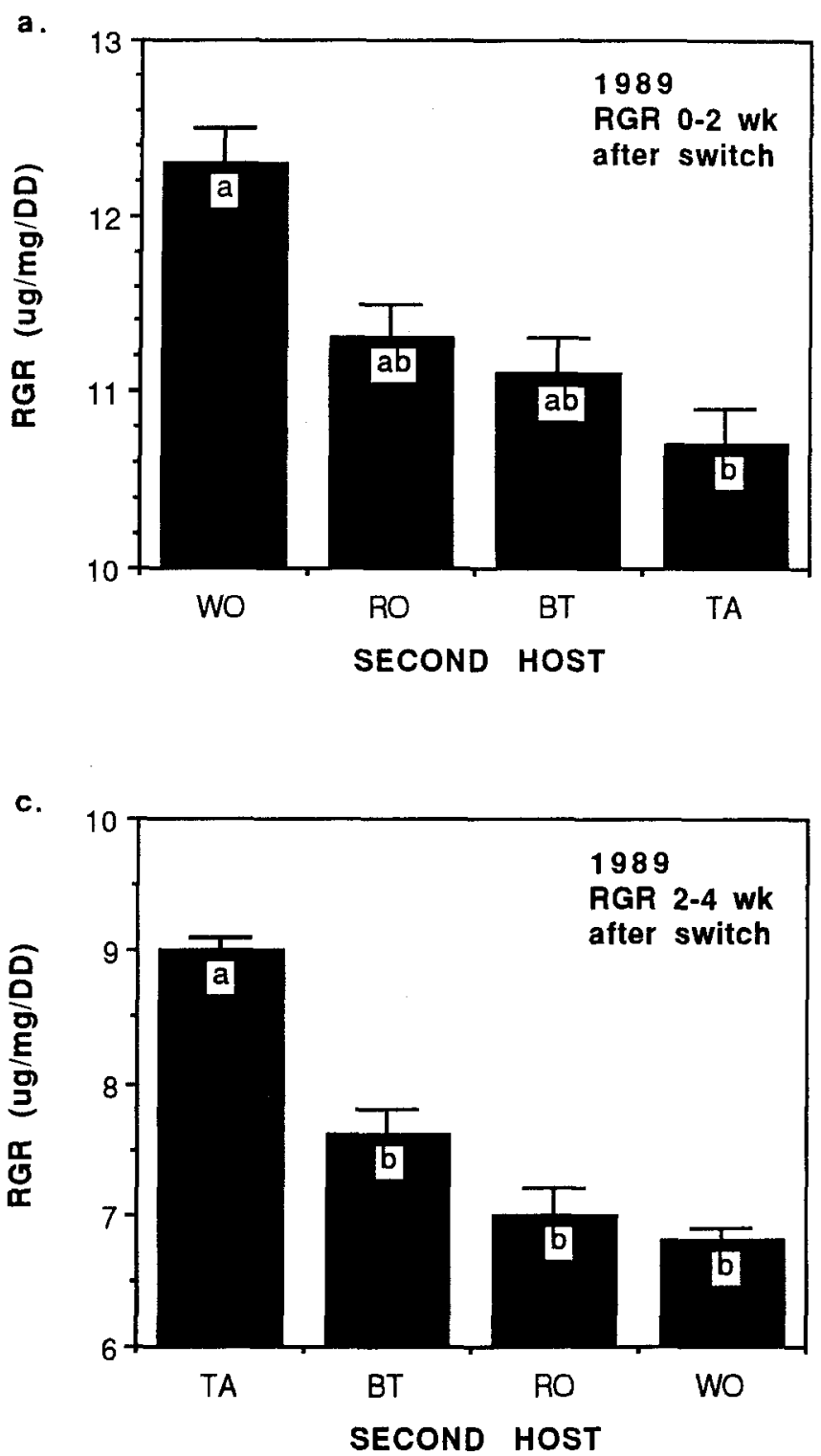

Fig. 4a-d Mean RGRs of larvae on different second host species for the period from zero to two weeks after a host switch in 1989 (a) and 1990 (b), and from two to four weeks after the switch in 1989 (c) and 1990 (d). ( $R O=$ red oak; $W O=$ white oak; $T A=$ trembling aspen; $B T=$ bigtooth aspen. Bars indicate standard errors. Different letters indicate mean values that are significantly different)

od after the switch (ANOVA sample 1 after switch: 1989 $p=0.976,1990 \quad p=0.734$; ANOVA sample 2 after switch: $1989 p=0.701,1990 p=0.251$ ).

\section{Larval development}

Larval development, measured as instar number, was not influenced meaningfully, either two weeks or four weeks after the switch, by the second host species eaten in either year. In 1989, while the ANOVA value for
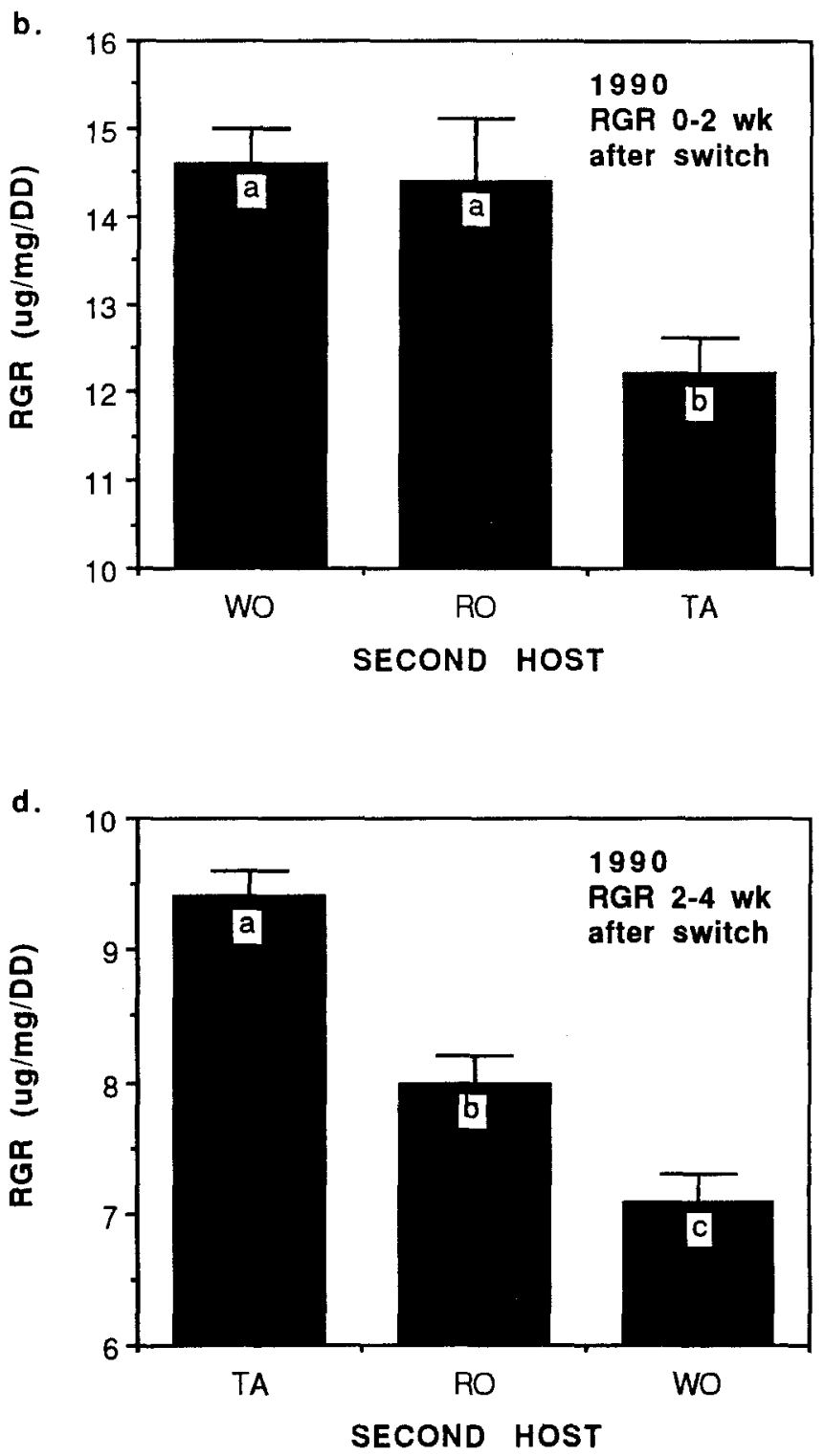

second host was statistically significant at two weeks after the host switch (ANOVA $p=0.010$ ) and nearly significant at four weeks after the host switch (ANOVA $p=0.058$ ), differences in mean values on the four host species were not biologically significant at either time (two weeks: bigtooth aspen $=3.9 \pm 0.02$ stadia, red oak $=3.8 \pm 0.03$ stadia, white oak $=3.8 \pm 0.03$ stadia, trembling aspen $=3.7 \pm 0.04$ stadia; four weeks: bigtooth aspen $=5.2 \pm 0.03$ stadia, white oak $=5.2 \pm 0.03$ stadia, trembling aspen $=5.1 \pm 0.03$ stadia, red oak $=5.1 \pm 0.03$ stadia). In 1990 , values were neither statistically nor biologically significantly different at either time period (ANOVA for second host at two weeks after switch $p=0.866$, four weeks after switch $p=0.331$ ).

Although second host species did not have any important influence on developmental levels, the first host species fed upon by the larvae had carry-over effects and continued to significantly affect developmental levels attained by larvae two weeks after the host switch took 
Table 4 Mean percent mortality of larvae on the various diet sequences for the two week period immediately following the host switch, ranked from largest to smallest percentages ${ }^{\mathbf{a}}$

\begin{tabular}{lllll}
\hline 1989 & & & 1990 \\
\cline { 1 - 1 } Diet & $\%$ Mortality & & Diet & $\%$ Mortality \\
\hline TA-TA & $10 \pm 4$ & WO-TA & $14 \pm 4$ \\
RO-TA & $8 \pm 3$ & TA-TA & $13 \pm 4$ \\
BT-TA & $7 \pm 2$ & RO-TA & $9 \pm 3$ \\
WO-TA & $7 \pm 3$ & TA-WO & $4 \pm 2$ \\
TA-RO & $7 \pm 2$ & WO-RO & $4 \pm 2$ \\
WO-BT & $4 \pm 2$ & RO-RO & $2 \pm 1$ \\
RO-RO & $4 \pm 2$ & RO-WO & $2 \pm 1$ \\
TA-BT & $4 \pm 2$ & WO-WO & $2 \pm 1$ \\
TA-WO & $4 \pm 1$ & TA-RO & $2 \pm 2$ \\
BT-RO & $3 \pm 2$ & & \\
RO-BT & $3 \pm 2$ & & \\
WO-RO & $3 \pm 2$ & & \\
BT-WO & $3 \pm 2$ & & \\
BT-BT & $2 \pm 1$ & & \\
RO-WO & $1 \pm 1$ & & \\
WO-WO & $0 \pm 0$ & & \\
\hline
\end{tabular}

${ }^{\mathrm{a}} \mathrm{RO}=$ red oak; $\mathrm{WO}=$ white oak; $\mathrm{TA}=$ trembling aspen; $\mathrm{BT}=$ bigtooth aspen Standard errors included

place in both years (ANOVA $1989 p=0.007,1990$ $p=0.023$ for first host). In 1989 larvae that fed on a first host of red oak were more advanced than all other larvae two weeks after the host switch and were on average 0.4 stadium ahead of, and significantly different from, the slowest developing group of larvae, which had fed on bigtooth aspen before the host switch (red oak $=4.0 \pm 0.01$ stadia, trembling aspen $=3.9 \pm 0.02$ stadia, white oak $=3.8 \pm 0.03$ stadia, bigtooth aspen $=3.6 \pm 0.03$ stadia; ANOVA $p=0.007$ for first host). The bigtooth aspen-started larvae were significantly behind larvae from all other host species in terms of their average development.

The situation was similar in 1990; larvae that had eaten red oak as their first host were significantly advanced on average over larvae from all other first host species and they were 0.5 stadia ahead of the slowest developing group (red oak $=3.8 \pm 0.03$ stadia, white oak $=3.5 \pm 0.06$ stadia, trembling aspen $=3.3 \pm 0.04$ stadia; ANOVA $p=0.023$ for first host). Four weeks after the host switch, developmental level of larvae on the various diet sequences had evened out and no biologically significant differences were present.

There were no significant interactions between first and second host at either sampling period after the switch in 1990 (ANOVA sampling period $1 p=0.848$, sampling period $2 p=0.572$ ) or at the second sampling period after the switch in 1989 (ANOVA $p=0.173$ ). At the first sampling period after the switch in 1989, however, there was a slightly significant interaction of first and second hosts (ANOVA $p=0.047$ ). The covariate of developmental level at the previous sampling period was significant for both sampling periods after the switch in 1989 and at the second sampling period after the switch in 1990 (ANOVA $p=0.0001$ for all times), but
Table 5 Mean developmental rates (days from hatch to pupation) for the two sexes on the various diet sequences in 1989 and 1990 , ranked from shortest to longest times ${ }^{a}$

\begin{tabular}{|c|c|c|c|c|}
\hline & \multicolumn{2}{|l|}{1989} & \multicolumn{2}{|l|}{1990} \\
\hline & Diet & Devel. time & Diet & Devel time \\
\hline Female & $\begin{array}{l}\text { RO-WO } \\
\text { TA-BT } \\
\text { TA-WO } \\
\text { RO-BT } \\
\text { WO-WO } \\
\text { RO-TA } \\
\text { BT-WO } \\
\text { RO-RO } \\
\text { WO-BT } \\
\text { BT-BT } \\
\text { TA-TA } \\
\text { BT-TA } \\
\text { WO-TA } \\
\text { TA-RO } \\
\text { WO-RO } \\
\text { BT-RO }\end{array}$ & $\begin{array}{l}53.1 \pm 1.0 \\
54.1 \pm 0.7 \\
54.3 \pm 1.0 \\
54.5 \pm 0.8 \\
55.4 \pm 1.3 \\
55.5 \pm 0.9 \\
56.2 \pm 1.1 \\
56.5 \pm 1.3 \\
56.6 \pm 1.2 \\
57.1 \pm 1.1 \\
57.3 \pm 1.1 \\
58.0 \pm 1.1 \\
58.2 \pm 1.0 \\
58.4 \pm 1.5 \\
58.6 \pm 1.0 \\
59.9 \pm 1.2\end{array}$ & $\begin{array}{l}\text { RO-WO } \\
\text { WO-WO } \\
\text { RO-TA } \\
\text { WO-TA } \\
\text { RO-RO } \\
\text { TA-WO } \\
\text { WO-RO } \\
\text { TA-RO } \\
\text { TA-TA }\end{array}$ & $\begin{array}{l}62.8 \pm 1.0 \\
67.0 \pm 1.1 \\
68.3 \pm 1.2 \\
68.5 \pm 1.3 \\
70.0 \pm 0.9 \\
70.4 \pm 1.4 \\
70.4 \pm 1.6 \\
71.1 \pm 1.2 \\
71.8 \pm 1.0\end{array}$ \\
\hline Male & $\begin{array}{l}\text { RO-WO } \\
\text { RO-BT } \\
\text { TA-TA } \\
\text { TA-BT } \\
\text { RO-RO } \\
\text { RO-TA } \\
\text { BT-BT } \\
\text { TA-WO } \\
\text { WO-TA } \\
\text { WO-WO } \\
\text { WO-BT } \\
\text { WO-RO } \\
\text { TA-RO } \\
\text { BT-WO } \\
\text { BT-TA } \\
\text { BT-RO }\end{array}$ & $\begin{array}{l}51.4 \pm 0.3 \\
51.8 \pm 0.6 \\
52.1 \pm 0.2 \\
52.1 \pm 0.7 \\
52.2 \pm 0.6 \\
52.3 \pm 0.5 \\
52.6 \pm 0.5 \\
52.8 \pm 0.7 \\
52.9 \pm 0.4 \\
53.7 \pm 1.0 \\
54.1 \pm 0.7 \\
54.5 \pm 1.0 \\
54.7 \pm 1.0 \\
54.7 \pm 0.8 \\
54.8 \pm 0.9 \\
55.8 \pm 1.1\end{array}$ & $\begin{array}{l}\text { RO-TA } \\
\text { WO-TA } \\
\text { WO-WO } \\
\text { RO-WO } \\
\text { RO-RO } \\
\text { TA-WO } \\
\text { TA-RO } \\
\text { WO-RO } \\
\text { TA-TA }\end{array}$ & $\begin{array}{l}63.5 \pm 1.0 \\
64.2 \pm 1.3 \\
64.3 \pm 1.1 \\
64.6 \pm 1.3 \\
64.9 \pm 0.7 \\
65.2 \pm 0.8 \\
66.3 \pm 2.0 \\
66.7 \pm 0.7 \\
66.9 \pm 1.5\end{array}$ \\
\hline
\end{tabular}

${ }^{a} \mathrm{RO}=$ red oak; $\mathrm{WO}=$ white oak; $\mathrm{TA}=$ trembling aspen; $\mathrm{BT}=$ bigtooth aspen Standard errors included

was not significant at the first sampling period after the switch in 1990 (ANOVA $p=0.349$ ).

Total larval development time (number of days from placement as neonates in the field to date of pupation) was different on the 16 switch types (Table 5). In 1989 , the difference between average development times of larvae from switch types that gave the fastest and slowest development was 4.4 days for males and 6.8 days for females. In 1990, the various diet types showed a range of 3.4 days difference in male development times and 9.0 days difference for female development times.

When results are pooled for insects in each year on the basis of host species that was the first element in their diets, average differences in development time of males from the four first host species were not biologically significant for either year. However, female data pooled in this manner showed a difference of 3.0 days between the fastest and slowest groups each year (Fig. 5). This carry-over effect of first host was statistically significant in 1989 (ANOVA $p=0.001$ for first host). Females having a first host of red oak in their diet se- 

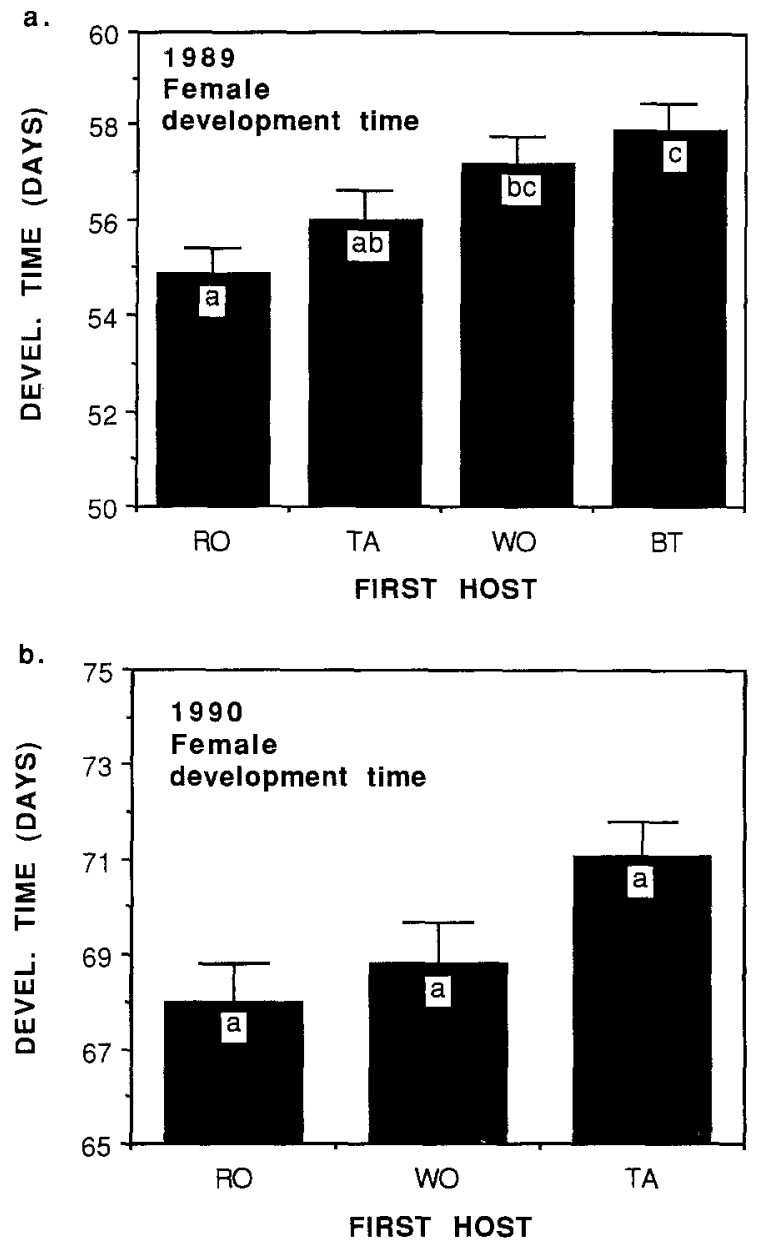

Fig. 5a, b Mean development times for females in 1989 (a) and 1990 (b) that were fed different first host diets. ( $R O=$ red oak; $W O=$ white oak; $T A=$ trembling aspen; $B T=$ bigtooth aspen. Bars indicate standard errors. Different letters indicate mean values that are significantly different)

quence developed fastest in 1989 , followed by females from trembling aspen, white oak, and bigtooth aspen (Fig. 5a). In 1990, the rank order on the basis of first host once again showed that insects from red oak had the fastest development, followed by insects from first hosts of white oak and trembling aspen, although differences were not strong enough to be statistically significant in 1990 (ANOVA $p=0.054$ for first host) (Fig. 5b).

While second host species consumed in a diet sequence did not significantly affect development times statistically for females (ANOVA $1989 p=0.074,1990$ $p=0.187$ for second host), there was a biologically significant difference in average development times of 3.7 days for females that fed on the different second host species in both years. Rank order from fastest to slowest developing groups in 1989 showed that insects on a second host of white oak had the shortest development times ( $54.5 \pm 0.6$ days), followed by insects on bigtooth aspen (55.4 \pm 0.5 days), trembling aspen $(57.1 \pm 0.5$ days), and finally red oak (58.2 \pm 0.7 days); 1990 was extremely similar with insects on a second host of white
Table 6 Mean pupal weights ( $\mathrm{mg}$ ) of the two sexes on the various diet sequences in 1989 and 1990, ranked from largest to smallest ${ }^{\text {a }}$

\begin{tabular}{|c|c|c|c|c|}
\hline & \multicolumn{2}{|l|}{1989} & \multicolumn{2}{|l|}{1990} \\
\hline & Diet & Weight & Diet & Weight \\
\hline Female & $\begin{array}{l}\text { RO-TA } \\
\text { WO-TA } \\
\text { TA-TA } \\
\text { BT-TA } \\
\text { WO-BT } \\
\text { WO-RO } \\
\text { RO-BT } \\
\text { TA-BT } \\
\text { BT-BT } \\
\text { BT-WO } \\
\text { RO-RO } \\
\text { RO-WO } \\
\text { BT-RO } \\
\text { WO-WO } \\
\text { TA-RO } \\
\text { TA-WO }\end{array}$ & $\begin{array}{l}1288 \pm 86 \\
1141 \pm 50 \\
1134 \pm 68 \\
1056 \pm 93 \\
925 \pm 102 \\
893 \pm 58 \\
891 \pm 106 \\
889 \pm 49 \\
880 \pm 35 \\
822 \pm 109 \\
795 \pm 75 \\
769 \pm 41 \\
763 \pm 59 \\
753 \pm 74 \\
722 \pm 53 \\
683 \pm 50\end{array}$ & $\begin{array}{l}\text { RO-TA } \\
\text { WO-TA } \\
\text { TA-TA } \\
\text { WO-WO } \\
\text { RO-RO } \\
\text { RO-WO } \\
\text { TA-RO } \\
\text { TA-WO } \\
\text { WO-RO }\end{array}$ & $\begin{array}{l}1444 \pm 68 \\
1429 \pm 85 \\
1294 \pm 49 \\
871 \pm 114 \\
858 \pm 63 \\
776 \pm 34 \\
747 \pm 48 \\
708 \pm 50 \\
698 \pm 48\end{array}$ \\
\hline Male & $\begin{array}{l}\text { TA-TA } \\
\text { RO-RO } \\
\text { WO-TA } \\
\text { RO-TA } \\
\text { BT-TA } \\
\text { WO-BT } \\
\text { TA-BT } \\
\text { TA-RO } \\
\text { RO-WO } \\
\text { RO-BT } \\
\text { BT-BT } \\
\text { WO-WO } \\
\text { TA-WO } \\
\text { WO-RO } \\
\text { BT-WO } \\
\text { BT-RO }\end{array}$ & $\begin{array}{l}409 \pm 13 \\
396 \pm 33 \\
395 \pm 17 \\
394 \pm 15 \\
391 \pm 9 \\
378 \pm 13 \\
351 \pm 17 \\
346 \pm 16 \\
346 \pm 16 \\
346 \pm 13 \\
339 \pm 13 \\
328 \pm 17 \\
320 \pm 17 \\
319 \pm 20 \\
318 \pm 24 \\
284 \pm 21\end{array}$ & $\begin{array}{l}\text { TA-TA } \\
\text { RO-TA } \\
\text { WO-TA } \\
\text { RO-RO } \\
\text { TA-RO } \\
\text { WO-RO } \\
\text { TA-WO } \\
\text { WO-WO } \\
\text { RO-WO }\end{array}$ & $\begin{array}{l}481 \pm 31 \\
480 \pm 31 \\
452 \pm 15 \\
383 \pm 21 \\
360 \pm 15 \\
340 \pm 14 \\
327 \pm 25 \\
284 \pm 30 \\
282 \pm 21\end{array}$ \\
\hline
\end{tabular}

${ }^{\mathrm{a}} \mathrm{RO}=$ red oak; WO $=$ white oak; TA $=$ trembling aspen; $\mathrm{BT}=$ bigtooth aspen Standard errors included

oak developing most quickly ( $66.7 \pm 1.0$ days), followed by those from trembling aspen (69.5 \pm 0.8 days), and insects on a second host of red oak ( $70.4 \pm 0.7$ days) once again being the slowest developing group.

There were no significant interactions between first host and second host that affected mean development times for males in either year (ANOVA $1989 p=0.259$, $1990 p=0.145$ ). Interaction between first host and second host was not significant in affecting female development times in 1989 (ANOVA $p=0.836$ ) but was significant in 1990 (ANOVA $p=0.041$ ). The covariate of instar at the final larval weighing period was not significant for either sex in either year except for males in 1990 (ANOVA male: $1989 p=0.181,1990 p=0.007$; female: $1989 p=0.398,1990 p=0.661$ ).

\section{Pupal weights}

Pupal weights were affected strongly and significantly by the type of second host species eaten for both sexes in 

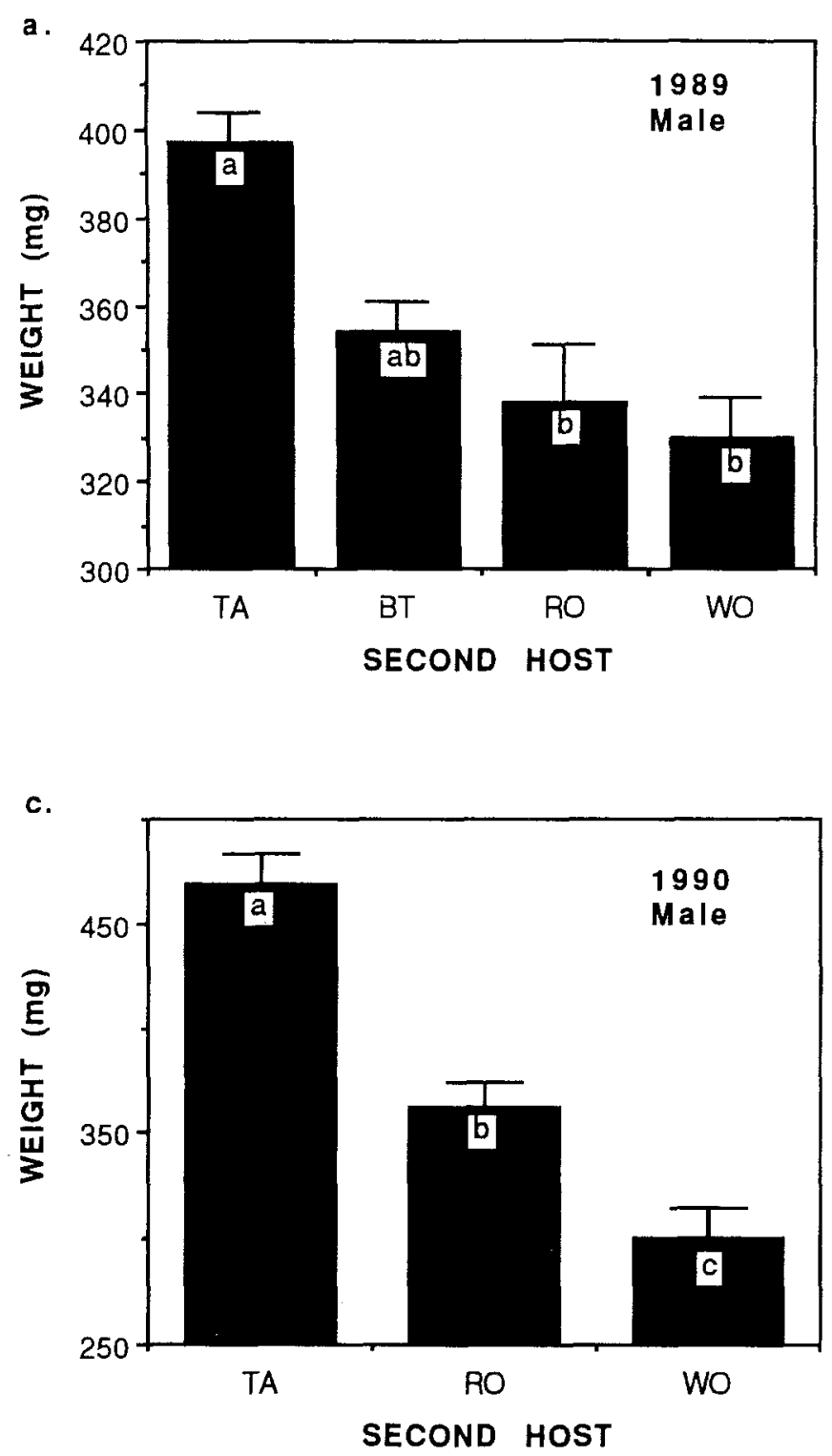

Fig. 6a-d Mean pupal weights of males (a) and females (b) in 1989 for insects that fed on the various second host species, and for males (c) and females (d) in 1990 on the various second host species. $(R O=$ red oak; $W O=$ white oak; $T A=$ trembling aspen; $B T=$ bigtooth aspen. Bars indicate standard errors. Different letters indicate mean values that are significantly different)

both years (ANOVA males: $1989 p=0.001,1990$ $p=0.0001$; females: $1989 p=0.0001,1990 p=0.0001$ for second host). In all cases, insects benefitted by feeding on a second host of trembling aspen (Fig. 6, Table 6). First host species fed upon did not have any significant effects on pupal weights (ANOVA male: $1989 p=0.063$, $1990 p=0.166$; female: $1989 p=0.393,1990 p=0.655$ ). There was no significant interaction of first and second host species affecting mean pupal weights of either males or females in either 1989 or 1990 (ANOVA males: $1989 p=0.234,1990 p=0.789$; female: $1989 p=0.993$, $1990 p=0.402)$. The covariate of weight at the final lar-
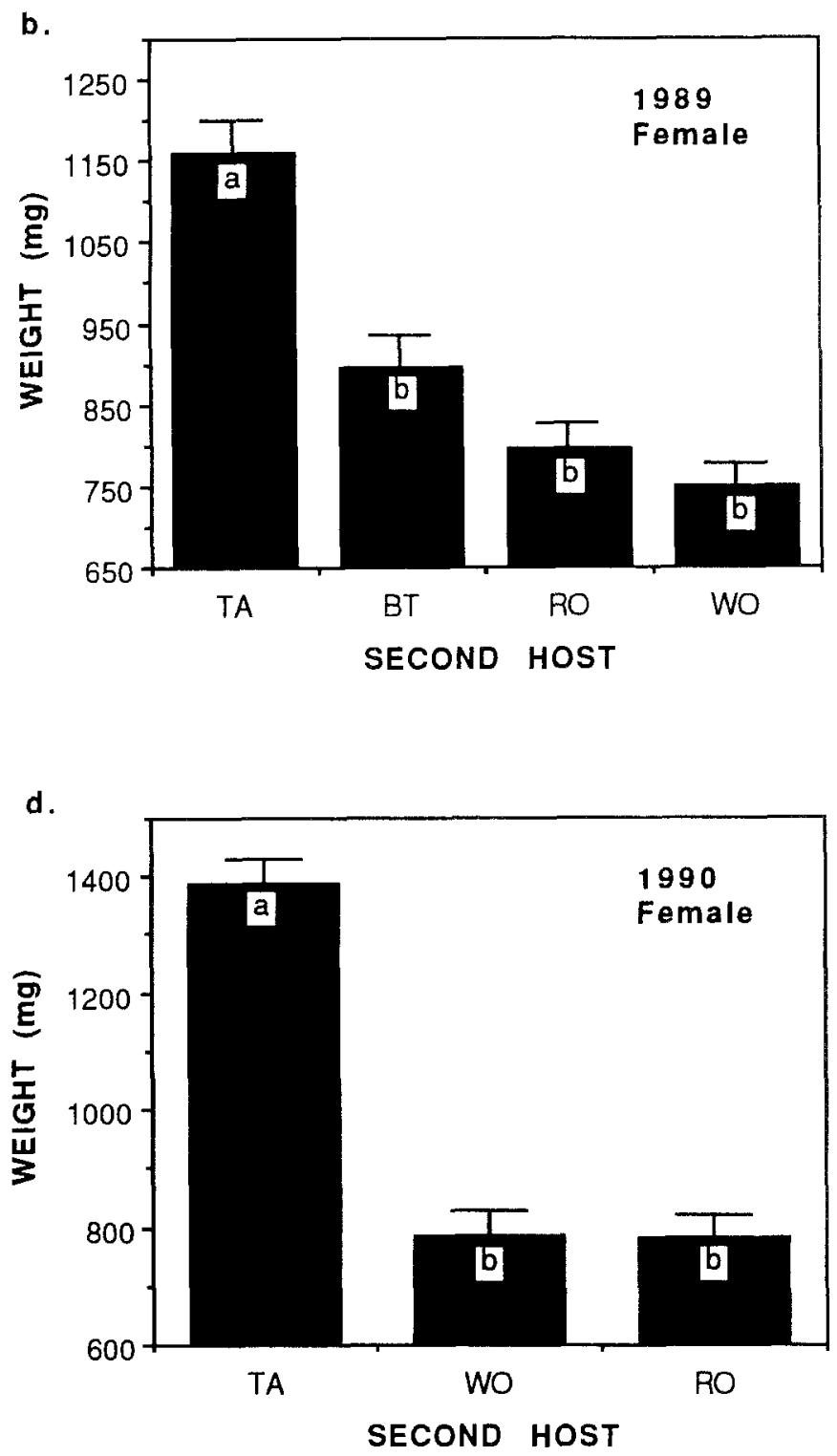

val weighing period was not significant for either sex in either year except for males in 1990 (ANOVA males: $1989 p=0.942,1990 p=0.025$; female: $1989 p=0.269$, $1990 p=0.839$ ).

\section{Discussion}

Gypsy moth performance is strongly affected by the host species that larvae eat in the field. Of the diets investigated in this study, early feeding on red oak followed by later feeding on an aspen, particularly trembling aspen, is of most benefit to insects in terms of attaining high levels of performance throughout their life.

Larvae that fed on a first host of red oak were ahead of larvae from the other host species in terms of mean weight, mean RGR, and mean level of larval development at the end of the initial two week feeding period. 
These field results fit well with the observations of others which indicate that oaks are among the most favored hosts of the gypsy moth (Leonard 1981). Additionally, laboratory trials have demonstrated that red oak foliage is very suitable for gypsy moths and is highly preferred by first instar larvae (Barbosa 1978b; Barbosa et al. 1979). Others have noted the faster larval development early in the season on red oak which we observed under controlled field conditions in this study (Campbell 1961; Barbosa 1978a). Young aspen leaves, on the other hand, have high levels of defensive compounds such as tremulacin, which can greatly prolong the gypsy moth's first stadium (Lindroth et al. 1987; Meyer and Montgomery 1987; Lindroth and Hemming 1990). This is consistent with our observations that the slowest developing group of insects at the first sampling period in both years were those from an aspen species. High levels of phenolics in young leaves of cottonwood (Populus deltoides Marsh.) also have been shown to cause depressed growth in gypsy moth larvae (Meyer and Montgomery 1987).

One factor contributing to red oak being a good early host for gypsy moths is the excellent synchrony that generally exists between gypsy moth egg hatch/first instar feeding initiation and springtime development of red oak foliage (Chilcote 1990). Such a match in timing is not the case with white oak, which breaks bud somewhat later and has extremely pubescent young leaves that are difficult for young insects to feed on, or with either of the aspen species (Chilcote 1990). Both aspen species can vary in time of budburst by as much as three weeks between clones of a single species at a given site (Barnes 1969; Chilcote 1990; Chilcote et al. 1992).

While aspen-fed insects did not perform as well initially, we found that insects switching onto trembling aspen as their later host species were ahead of other larvae in terms of average larval weights, RGRs, and pupal weights attained by both sexes at the end of the season. Female pupae that had fed as larvae on a second host of trembling aspen were approximately 1.5 times heavier than female pupae resulting from larvae that ate either oak species as their second host in 1989. Similarly in 1990, females fed a second host of trembling aspen reached pupal weights averaging approximately 1.8 times greater than those insects that fed on a second host of either red or white oak. When bigtooth aspen was included in the experiments, it always ranked in second place as a host for RGR and pupal weights, ahead of the two oak species. Roden and Surgeoner (1991) have found in laboratory work that gypsy moth larvae reared on trembling aspen, white birch (Betula papyrifera Marsh.), or diet combinations that included either of these species produced larger pupae than did the other types of foliage combinations that they tested. Research with cottonwood has shown that gypsy moth larvae prefer and grow better on the older foliage of this poplar species than they do on the younger leaves (Meyer and Montgomery 1987). One of the reasons that aspens may be better hosts than oak species later on in the season is that protein contents of both bigtooth aspen and trembling aspen remain higher than the protein contents of oaks such as red oak and black oak (Keating et al. 1988). Also, pupal mass and fecundity of the gypsy moth are negatively correlated with concentrations of total phenolics and hydrolyzable tannins in the diet but positively correlated with condensed tannin concentration (Rossiter et al. 1988), and both bigtooth and trembling aspens are significantly lower in hydrolyzable tannins and significantly higher in condensed tannins than red, black, and white oaks (Keating et al. 1988; Keating et al. 1990). The reason that bigtooth aspen-fed larvae do not perform quite as well as trembling aspen-fed larvae may be due to bigtooth aspen having higher tremulacin levels on average than trembling aspen (Lindroth et al. 1987).

Although insects feeding on aspens as later hosts perform better in terms of weight gains, RGRs, and pupal weights than larvae on second hosts of oaks, insects eating aspens may experience somewhat longer time periods for development. While Roden and Surgeoner (1991) indicated that larvae developed faster on trembling aspen or diet combinations including trembling aspen, Lindroth and Weisbrod (1991) found that aspen phenolic glycosides led to slowed rates of development in older larvae. Our study indicates that those insects that fed on either trembling aspen or red oak as the second species in their diets were behind white oak-fed larvae in terms of total development times. Depressed growth rates on red oak during later instars were likewise noted in observations by Campbell (1961).

Larvae eating either aspen species as the second plant in a diet sequence also may be negatively affected due to complex relationships that exist between diet and larval infection with gypsy moth nucleopolyhedrosis virus (NPV). We observed that NPV was the major mortality agent in our study, and we found much higher mortality rates for those groups of larvae that consumed trembling aspen during the latter part of the season than for those eating diet sequences ending on oak. Alkaline gut conditions are required for virus solubility and infection with NPV to take place (Schultz and Lechowicz 1986). Because of the less acid nature of aspen foliage in comparison to oak foliage, caterpillars that consume virus-contaminated aspen foliage have much more alkaline gut $\mathrm{pHs}$ and have also been shown by others to suffer much higher infection and mortality rates than do those larvae that eat oak (Schultz and Lechowicz 1986; Keating and Yendol 1987; Keating et al. 1988; Keating et al. 1990).

Many workers have found deleterious effects of host switching on the performance of various lepidopteran larvae. Such effects may range from temporarily lessened food consumption to suppressed growth rates, decreased efficiency of nutrient use, lowered pupal weights, and increased mortality levels (Jermy et al. 1968; Schoonhoven and Meerman 1978; Scriber 1979, 1981, 1982; Grabstein and Scriber 1982; Karowe 1989). The limited host switching work that has been done on 
gypsy moths in the past has indicated in the laboratory that switching between suitable diet items generally does not cause great harm for gypsy moths, although insects on some diet sequences performed more poorly than insects on certain other diet sequences (Barbosa et al. 1986; Roden and Surgeoner 1991). In some cases, larvae benefitted by making host switches between appropriate diet items (Barbosa 1978b; Barbosa et al. 1986; Roden and Surgeoner 1991). Our study using large sample sizes and a variety of switch combinations confirms that gypsy moth larvae under field conditions do not show any ultimately negative impacts from a switch among favorable host species, but indeed may greatly benefit if correct host sequences are selected. A1so, larvae that fed on a single species for the entire season were not discriminably benefitted or hurt by absence of a host switch; larvae fed constant diets of the various host species did not perform consistently better or worse than larvae fed mixed diets. Rather, the results show that insect performance was affected by the types of host species eaten and the time during the larval season that these species were consumed instead of by whether larvae ate single species diets or mixed species diets.

When gypsy moths switch between host species, it may take some time for them to adjust to their new food plant both behaviorally and physiologically. Although aspens are ultimately the most beneficial second host species for larvae in terms of weights and RGRs attained, the positive effects of aspen species on larval weights and RGRs did not immediately show up after the host switch took place in this study. In the two week period directly after the switch, average weights and RGRs of larvae that fed on a second host of oak, particularly white oak, were generally ranked ahead of those on a second host of aspen. This may occur because oaks are highly favored food plants of the gypsy moth and because gypsy moth larvae seem to retain some preference for oaks, such as red oak, even if reared on another type of plant during their early instars (Barbosa et al. 1979). It is possible that after a host switch, larvae on oaks begin to feed more readily at first than larvae on aspens do and that insects switched to oaks therefore have higher relative consumption rates initially, leading to availability of a greater assimilate pool and faster growth for these insects than for those on aspen until adjustment takes place (Waldbauer 1964; Appel and Martin 1992). White oak may show up as more beneficial at this sampling period than red oak because its foliage generally flushes later than that of red oak, so its leaves would be somewhat less mature at this point in the season (Chilcote 1990).

Insect performance on a multiple species sequential diet may be strongly affected by the time at which a move between host plants is made.. First, insects of different ages may have differing abilities to accomodate a change in diet; older insects may be more able in some cases to successfully handle a wide range of food materials than younger insects can. For example, gypsy moth early instars generally will not feed on conifers, whereas older instars can feed on conifers with ease and in general attack a wider range of host plants than do the early instars (Barbosa 1978a and b; Leonard 1981; Mauffette and Lechowicz 1984). Ability of insects to detoxify various plant compounds may change as well as insects age (Benke and Wilkinson 1971; Wilkinson and Brattsten 1972; Ahmad and Forgash 1973, 1975; Forgash and Ahmad 1974). In some cases, experience on a particular type of host may cause behavioral or physiological mechanisms to become set in insects so that it is difficult for them to efficiently utilize a new host plant (Jermy et al. 1968; Yamamoto 1974; Hanson 1976; Greenblatt et al. 1978; Schoonhoven and Meerman 1978; Scriber 1979, 1981, 1982; Grabstein and Scriber 1982; Ahmad 1983; Redfearn and Pimm 1988; Karowe 1989). Finally, the developmental stage of the plant at the time it is fed upon by an insect can affect the insect's performance (Raupp and Denno 1983). Because of the importance of these factors, all of which have strong temporal components, additional study should be done examining effects that timing of host switches have on herbivore performance when host switching is an important component of an organism's life history.

Acknowledgements We thank G.W. Fowler for statistical consultation in this study. The work was supported by the McIntireStennis Cooperative Forestry Research Act (PL 87-188), the United States Department of Agriculture-United States Forest Service, and The University of Michigan. The Michigan Department of Natural Resources provided summer housing for research participants.

\section{References}

Ahmad S (1983) Mixed-function oxidase activity in a generalist herbivore in relation to its biology, food plants, and feeding history. Ecology 64:235-243

Ahmad S, Forgash AJ (1973) NADPH oxidation by microsomal preparations of gypsy moth larval tissues. Insect Biochem $3: 263-273$

Ahmad S, Forgash AJ (1975) NADPH-cytochrome-c-reductase: changes in specific activity in gypsy moth larvae. J Insect Physiol 21:85-88

Allen JC (1976) A modified sine wave method for calculating degree days. Environ Entomol 5:388-396

Appel HM, Martin MM (1992) Significance of metabolic load in the evolution of host specificity of Manduca sexta. Ecology 73:216-228

Barbosa P (1978a) Distribution of an endemic larval gypsy moth population among various tree species. Environ Entomol 7:526-527

Barbosa P (1978b) Host plant exploitation by the gypsy moth, Lymantria dispar. Ent Exp Appl 24:28-37

Barbosa P, Greenblatt J (1979) Suitability, digestibility and assimilation of various host plants of the gypsy moth Lymantria dispar L. Oecologia 43:111-119

Barbosa P, Greenblatt J, Withers W, Cranshaw W, Harrington EA (1979) Host-plant preferences and their induction in larvae of the gypsy moth, Lymantria dispar. Ent Exp Appl 26:180-188

Barbosa P, Waldvogel M, Martinat P, Douglass LW (1983) Developmental and reproductive performance of the gypsy moth, Lymantria dispar (L.) (Lepidoptera: Lymantriidae), on selected hosts common to mid-Atlantic and southern forests. Environ Entomol 12:1858-1862 
Barbosa P, Martinat P, Waldvogel M (1986) Development, fecundity and survival of the herbivore Lymantria dispar and the number of plant species in its diet. Ecol Ent 11:1-6

Barnes BV (1969) Natural variation and delineation of clones of Populus tremuloides and P. grandidentata in northern lower Michigan. Silvae Genet 18:130-142

Beach RM, Todd JW (1988) Foliage consumption and developmental parameters of the soybean looper and the velvetbean caterpillar (Lepidoptera: Noctuidac) reared on susceptible and resistant soybean genotypes. J Econ Entomol 81:310-316

Beckwith RC (1976) Influence of host foliage on the Douglas-fir tussock moth. Environ Entomol 5:73-77

Benke GM, Wilkinson CF (1971) In vitro microsomal epoxidase activity and susceptibility to carbaryl and carbaryl-piperonyl butoxide combinations in house crickets of different age and sex. J Econ Entomol 64:1032-1034

Brattsten LB (1979) Ecological significance of mixed-function oxidations. Drug Metabol Rev 10:35-58

Campbell RW (1961) Population dynamics of the gypsy moth. $\mathrm{PhD}$ dissertation. University of Michigan, Ann Arbor. $172 \mathrm{p}$

Capinera JL, Barbosa P (1976) Dispersal of first-instar gypsy moth larvae in relation to population quality. Oecologia $26: 53-64$

Chilcote CA (1990) The effects of host phenology and site interactions on the gypsy moth, Lymantria dispar. $\mathrm{PhD}$ dissertation. University of Michigan, Ann Arbor. $167 \mathrm{p}$

Chilcote CA, Witter JA, Montgomery ME, Stoyenoff JL (1992) Intra- and interclonal variation in gypsy moth larval performance on bigtooth and trembling aspen. Can J For Res 22:1676-1683

Crawley MJ, Akhteruzzaman (1988) Individual variation in the phenology of oak trees and its consequences for herbivorous insects. Functional Ecol 2:409-415

Doane CC, Leonard DE (1975) Orientation and dispersal of latestage larvae of Porthetria dispar (Lepidoptera: Lymantriidae). Can Entomol 107:1333-1338

Drooz AT (1965) Some relationships between host, egg potential and pupal weight of the elm spanworm, Ennomos subsignarius (Lepidoptera: Geometridae). Ann Entomol Soc Amer 58:243245

Drooz AT (1970) The elm spanworm (Lepidoptera: Geometridae): how several natural diets affect its biology. Ann Entomol Soc Amer 63:391-397

Feeny $\mathrm{P}(1970)$ Seasonal changes in oak leaf tannins and nutrients as a cause of spring feeding by winter moth caterpillars. Ecology $51: 565-581$

Feeny P (1976) Plant apparency and chemical defense. In: Wallace JW, Mansell RL (eds) Recent advances in phytochemistry 10. Plenum Press, New York, pp 1-40

Feeny P, Blau WS, Kareiva PM (1985) Larval growth and survivorship of the black swallowtail butterfly in central New York. Ecol Monogr 55:167-187

Forgash AJ, Ahmad S (1974) Demethylation and hydroxylation by gut-microsomes of gypsy moth larvae. Int $\mathrm{J}$ Biochem 5 : $11-15$

Garcia EF (1988) Spring and summer hosts for Pieris rapae in southern Spain with special attention to Capparis spinosa. Ent Exp Appl 48:173-178

Grabstein EM, Scriber JM (1982) Host-plant utilization by Hyalophora cecropia as affected by prior feeding experience. Ent Exp Appl 32:262-268

Greenblatt JA, Calvert WH, Barbosa P (1978) Larval feeding preferences and inducibility in the fall webworm, Hyphantria cunea. Ann Entomol Soc Am 71:605-606

Hajek AE (1989) Effects of transferring gypsy moth, Lymantria dispar, larvae between artificial diet and Quercus rubra foliage. Ent Exp Appl 51:141-148

Hanson FE (1976) Comparative studies on induction of food choice preferences in lepidopterous larvae. In: Jermy T (ed) The host-plant in relation to insect behavior and reproduction. Symp Biol Hung 16:71-77
Hanson FE (1983) The behavioral and neurophysiological basis of food plant selection by lepidopterous larvae. In: Ahmad S (ed) Herbivorous insects: host-seeking behavior and mechanisms. Academic Press, New York, pp 3-23

Holliday NJ (1977) Population ecology of winter moth (Operophtera brumata) on apple in relation to larval dispersal and time of budburst. J Appl Ecol 14:803-813

Hough JA, Pimentel D (1978) Influences of host foliage on development, survival, and fecundity of the gypsy moth. Environ Entomol 7:97-102

Ishaaya I, Swirski E (1976) Trehalase, invertase and amylase activities in the black scale, Saissetia oleae and their relation to host adaptability. J Insect Physiol 22:1025-1029

Jermy T, Hanson FE, Dethier VG (1968) Induction of specific food preference in lepidopterous larvae. Ent Exp Appl 11:211-230

Karowe DN (1989) Facultative monophagy as a consequence of prior feeding experience: behavioral and physiological specialization in Colias philodice larvae. Oecologia 78:106-111

Keating ST, Yendol WG (1987) Influence of selected host plants on gypsy moth (Lepidoptera: Lymantriidae) larval mortality caused by a baculovirus. Environ Entomol 16:459-462

Keating ST, Yendol WG, Schultz JC (1988) Relationship between susceptibility of gypsy moth larvae (Lepidoptera: Lymantriidae) to a baculovirus and host plant foliage constituents. Environ Entomol 17:952-958

Keating ST, Hunter MD, Schultz JC (1990) Leaf phenolic inhibition of gypsy moth nuclear polyhedrosis virus: role of polyhedral inclusion body aggregation. J Chem Ecol 16:1445-1457

Kogan M, Cope D (1974) Feeding and nutrition of insects associated with soybeans. 3. Food intake, utilization, and growth in the soybean looper, Pseudoplusia includens. Ann Entomol Soc Amer 67:66-72

Koller CN, Leonard DE (1981) Comparison of energy budgets for spruce budworm Choristoneura fumiferana (Clemens) on balsam fir and white spruce. Oecologia 49:14-20

Lance DL, Barbosa P (1979) Dispersal of larval Lepidoptera with special reference to forest defoliators. Biologist 61:90-110

Lance D, Barbosa P (1981) Host tree influences on the dispersal of first instar gypsy moths, Lymantria dispar (L.). Ecol Ent 6:411416

Lance D, Barbosa P (1982) Host tree influences on the dispersal of late instar gypsy moths, Lymantria dispar. Oikos 38:1-7

Larsson S, Ohmart CP (1988) Leaf age and larval performance of the leaf beetle, Paropsis atomaria. Ecol Entomol 13:19-24

Leonard DE (1967) Silking behavior of the gypsy moth, Porthetria dispar. Can Entomol 99:1145-1149

Leonard DE (1970) Feeding rhythm in larvae of the gypsy moth. J Econ Entomol 63:1454-1457

Leonard DE (1981) Bioecology of the gypsy moth. In: Doane CC, McManus MM (eds) The gypsy moth: research toward integrated pest management. Forest Service Tech Bull 1584, USDA, Washington, D.C., pp 8-29

Liebhold AM, Elkinton JS, Wallner WE (1986) Effect of burlap bands on between-tree movement of late-instar gypsy moth, Lymantria dispar (Lepidoptera: Lymantriidae). Environ Entomol 15:373-379

Lindroth RL, Hemming JC (1990) Responses of the gypsy moth (Lepidoptera: Lymantriidae) to tremulacin, an aspen phenolic glycoside. Environ Entomol 19:842-847

Lindroth RL, Weisbrod AV (1991) Genetic variation in response of the gypsy moth to aspen phenolic glycosides. Biochem System Ecol 19:97-103

Lindroth RL, Hsia MTS, Scriber JM (1987) Seasonal patterns in the phytochemistry of three Populus species. Biochem System Ecol 15:681-686

Mauffette Y, Lechowicz MJ (1984) Differences in the utilization of tree species as larval hosts and pupation sites by the gypsy moth, Lymantria dispar (Lepidoptera: Lymantriidae). Can Entomol 116:685-690

Meyer GA, Montgomery ME (1987) Relationships between leaf age and the food quality of cottonwood foliage for the gypsy moth, Lymantria dispar. Oecologia 72:527-532 
Miller JC, Hanson PE (1989) Laboratory studies on development of gypsy moth, Lymantria dispar (L.) (Lepidoptera: Lymantriidae), larvae on foliage of gymnosperms. Can Entomol $121: 425-429$

Miller JC, Hanson PE, Kimberling DN (1991) Development of the gypsy moth (Lepidoptera: Lymantriidae) on Garry oak and red alder in western North America. Environ Entomol 20:1097-1101

Mitter C, Futuyma DJ, Schneider JC, Hare JD (1979) Genetic variation and host plant relations in a parthenogenetic moth. Evol 33:777-790

Neter J, Wasserman W, Kutner MH (1990) Applied linear statistical models. Irvin, Homewood, IL

ODell TM, Butt CA, Bridgeforth AW (1985) Lymantria dispar. In: Singh P, Moore RF (eds) Handbook of insect rearing, vol II. Elsevier, Amsterdam, pp 355-367

Rafes PM, Gninenko YI (1973) The survival of leaf eating caterpillars (Lepidoptera) as related to their behavior. Entomol Rev 52:204-211

Raupp MJ, Denno RF (1983) Leaf age as a predictor of herbivore abundance. In: Denno RF, McClure MS (eds) Variable plants and herbivores in natural and managed systems. Academic Press, New York, pp 91-124

Raupp MJ, Warren JH, Sadof CS (1988) Effects of short term phenological changes in leaf suitability on the survivorship, growth, and development of the gypsy moth (Lepidoptera: Lymantriidae) larvae. Environ Entomol 17:316-319

Rausher MD (1983) Ecology of host-selection behavior in phytophagous insects. In: Denno RF, McClure MS (eds) Variable plants and herbivores in natural and managed systems. Academic Press, New York, pp 223-257

Redfearn A, Pimm SL (1988) Population variability and polyphagy in herbivorous insect communities. Ecol Monogr $58: 39-55$

Roden DB, Surgeoner GA (1991) Survival, development time, and pupal weights of larvae of gypsy moth reared on foliage of common trees of the upper Great Lakes region. North J Appl For 8:126-128

Rossiter MC (1981) Factors contributing to host range extension in the gypsy moth, Lymantria dispar. PhD dissertation. State Univ of New York, Stony Brook

Rossiter MC, Schultz JC, Baldwin IT (1988) Relationships among defoliation, red oak phenolics, and gypsy moth growth and reproduction. Ecology 69:267-277

SAS (1985) SAS user's guide: statistics. SAS Institute, Cary, North Carolina
Schoonhoven LM, Meerman J (1978) Metabolic cost of changes in diet and neutralization of allelochemics. Ent Exp Appl 24:689-693

Schultz JC, Lechowicz MJ (1986) Hostplant, larval age, and feeding behavior influence midgut $\mathrm{pH}$ in the gypsy moth (Lymantria dispar). Oecologia 71:133-137

Schweitzer DF (1979) Effects of foliage age on body weight and survival of larvae of the tribe Lithophanini (Lepidoptera: Noctuidae). Oikos 32:403-408

Scriber JM (1979) The effects of sequentially switching foodplants upon biomass and nitrogen utilization by polyphagous and stenophagous Papilio larvae. Ent Exp Appl 25:203-215

Scriber JM (1981) Sequential diets, metabolic costs, and growth of Spodoptera eridania (Lepidoptera: Noctuidae) feeding upon dill, lima bean, and cabbage. Oecologia 51:175-180

Scriber JM (1982) The behavior and nutritional physiology of southern armyworm larvae as a function of plant species consumed in earlier instars. Ent Exp Appl 31:359-369

Scriber JM, Feeny P (1979) Growth of herbivorous caterpillars in relation to feeding specialization and to the growth form of their host plants. Ecology 60:829-850

Sheehan KA (1992) User's guide for GMPHEN: gypsy moth phenology model. USDA-USFS, NEFES, Tech Rept NE-158

Sheppard CA, Friedman S (1990) Influence of host plant, foliar phenology and larval dietary history on Lymantria dispar larval nutritional indices. Ent Exp Appl 55:247-255

Soo Hoo CF, Fraenkel G (1966) The consumption, digestion, and utilization of food plants by a polyphagous insect, Prodenia eridania (Cramer). J Insect Physiol 12:711-730

Ticehurst M, Yendol W (1989) Distribution and abundance of early instar gypsy moth (Lepidoptera: Lymantriidae) in forests during day and night. Environ Entomol 18:459-464

Waldbauer GP (1964) The consumption, digestion, and utilization of Solanaceous and non-Solanaceous plants by larvae of the tobacco hornworm, Protoparce sexta (Johan.) (Lepidoptera: Sphingidae). Ent Exp Appl 7:253-269

Wilkinson CF, Brattsten LB (1972) Microsomal drug metabolizing enzymes in insects. Drug Metab Rev 1:153-228

Yamamoto RT (1974) Induction of hostplant specificity in the tobacco hornworm, Manduca sexta. J Insect Physiol 20:641650

Yu SJ (1982) Induction of microsomal oxidases by host-plants in the fall armyworm, Spodoptera frugiperda (J.E. Smith). Pesticide Biochem Physiol 17:59-67 